\title{
Reversible and Irreversible Binding of Nanoparticles to Polymeric Surfaces
}

\author{
Wolfgang H. Binder, ${ }^{1}$ Marina Lomoschitz, ${ }^{2}$ Robert Sachsenhofer, ${ }^{1}$ \\ and Gernot Friedbacher ${ }^{3}$ \\ ${ }^{1}$ Institute of Macromoleculare Chemistry, Martin-Luther-Universität Halle-Wittenberg,
Heinrich-Damerowstrasse 4/TGZ III, 06120 Halle, Germany
${ }^{2}$ Institut für Materialchemie 165, Technische Universität Wien, Getreidemarkt 9/165, 1080 Wien, Austria
${ }^{3}$ Institut für Chemische Technologien und Analytik 164, Technische Universität Wien, Getreidemarkt 9/164, 1080 Wien, Austria
}

Correspondence should be addressed to Wolfgang H. Binder, wolfgang.binder@chemie.uni-halle.de

Received 15 October 2008; Accepted 24 March 2009

Recommended by Michael Wong

\begin{abstract}
Reversible and irreversible binding of CdSe-nanoparticles and nanorods to polymeric surfaces via a strong, multiple hydrogen bond (= Hamilton-receptor/barbituric acid) is described. Based on ROMP-copolymers, the supramolecular interaction on a thin polymer film is controlled by living polymerization methods, attaching the Hamilton-receptor in various architectures, and concentrations. Strong binding is observed with CdSe-nanoparticles and CdSe-nanorods, whose surfaces are equipped with matching barbituric acid-moieties. Addition of polar solvents, able to break the hydrogen bonds leads to the detachment of the nanoparticles from the polymeric film. Irreversible binding is observed if an azide/alkine-"click"-reaction is conducted after supramolecular recognition of the nanoparticles on the polymeric surface. Thus reversible or irreversible attachment of the nanosized objects can be achieved.
\end{abstract}

Copyright ( $) 2009$ Wolfgang H. Binder et al. This is an open access article distributed under the Creative Commons Attribution License, which permits unrestricted use, distribution, and reproduction in any medium, provided the original work is properly cited.

\section{Introduction}

Assembly of nanosized objects [1] is an important step towards the generation of functional materials, that is, for applications in microelectronics [2], medicine [3], and sensor-applications [4]. As outlined in a series of recent review-papers $[5,6]$ basically four principles exist to direct a selective and specific assembly of nanoparticles onto surfaces or interfaces: (a) interfacial effects in liquid/liquid-systems [7] (b) crystallization of colloids (c) shape-dependent ordering, and (d) template-directed self assembly processes mediated by supramolecular bonds [8]. In all described cases an important point concerns the possibility to control the reversibility of the binding/assembly processes, since often physical properties of the final aggregate are strongly dependent on the underlying ordering processes. Both can be achieved by carefully adjusting the size and adsorption energy between the interfacial contact and the nanoparticles surface. Examples of such processes have been described via size-selective control of nanoparticle-binding at liquid/liquid-interfaces as reported by Duan et al. [9], and Böker et al. [10], or the location of nanoparticles at polymeric interfaces [11-14] due to entropic or interfacial effects. In the first case [9] smaller nanoparticles display lower interaction energies in comparison to large-sized nanoparticles, thus allowing to selectively remove the smaller particles from the interface after addition of the large ones; in the latter case entropic constraints direct smaller, noninteracting nanoparticles to the polymer interface of block copolymers by entropic chain effects [11, 13], whereas selective location of larger nanoparticles can be achieved by appropriate surface engineering [12].

The supramolecular recognition concept overcomes the selection between larger- or smaller-sized nanoparticles by introducing directed, specific, and stronger interactions. Thus various hydrogen bonding systems [15] (i.e., Rotellos thymine/triazine-; $[16,17]$ our Hamiltonreceptor/barbituric acid system [18, 19, 29], or Reinhoudts triazine/barbiturate-system [21]), and Reinhoudts molecular printboards (relying on cyclodextrin-inclusion complexes 
[22]) have been used to direct the assembly of nanoparticles to surfaces or interfaces. The big advantage of such supramolecular systems over the purely interfacially controlled is their specificity of binding, which does not select between larger or smaller nanoparticles, but just selects the binding event due to the supramolecular interaction between the nanoparticles surface and the underlying scaffold. However, a disadvantage concerns the irreversibility of the binding event, since a relatively strong interaction energy of $E>10 k_{B} T$ is needed to overcome the translational energy of the smaller nanoparticles $[7,19]$ often leading to irreversible binding processes. Thus, the ideal combination would be an initially strong interaction, which allows reversibility and subsequent irreversible binding.

In the present paper, we describe a different concept of controlling the reversible/irreversible attachment of nanoparticles and nanorods to polymeric surfaces via directed supramolecular interactions and subsequent covalent fixation, as described in Figure 1: thus binding of nanoparticles or nanorods is mediated by distinct multiple hydrogen bonds, attached to a polymeric surface of defined architectures (either a statistical homopolymer or a block copolymer) (case (a) or case (b)). In these cases, the recognition is entirely mediated via the specificity of the multiple hydrogen bond (Hamiltonfreceptor/barbiturate), acting between the surface of barbiturate-modified-CdSenanoparticles or nanorods, and a polymeric scaffold, presenting the Hamilton-receptor in a specific architecture. Thus, the binding is reversible, since the strength of the hydrogen bond can be weakened from its initial association constant of $\sim 10^{5} \mathrm{M}^{-1}$ ion nonpolar solvents to $\sim 15 \mathrm{M}^{-1}$ in polar solvents such as methanol [18].

However, (approach (c)), if a possibility exists to mediate a chemical reaction between the attached nanoparticles and the surface after recognition, then an irreversible attachment would result. The main question in this case concerns the conditions of this chemical attachment, which must take place still preserving the supramolecular interaction between the nanoparticle and the surface. To this purpose, we have chosen the azide/alkin-"click"-reaction, which is a $\mathrm{Cu}(\mathrm{I})$ mediated 1,3-dipolar-cycloaddition reaction [23, 24], able to mediate reactions under extremely moderate reaction conditions (i.e., without increase in temperature, solvent- and substrate insensitive) [25-27]. The following paper focuses on these issues, demonstrating the reversible/irreversible attachment of CdSe-nanoparticles and CdSe-nanorods onto specifically engineered polymeric surfaces via supramolecular concepts and subsequent covalent fixation.

\section{Experimental Section}

Solvents and Reagents. Methanol was dried over $\mathrm{CaH}_{2}$ refluxing for 24 hours, distilled and stored with activated Klinosorb $3 \AA$ molecular sieve. Tetrahydrofuran (THF) was refluxed over sodium wires and benzophenone over night, distilled and stored with activated Klinosorb $4 \AA$ molecular sieve. Chloroform and dichloromethane were refluxed over $\mathrm{K}_{2} \mathrm{CO}_{3}$, distilled and stored with activated
Klinosorb $4 \AA$ molecular sieve. DMF was refluxed with calcium hydride, distilled and stored with activated Klinosorb $4 \AA$ molecular sieve. Toluene was refluxed over sodium wires, distilled and stored with Klinosorb $4 \AA$ molecular sieve. Diethyl ether was refluxed over sodium wires and benzophenone over night, distilled and stored with activated Klinosorb $3 \AA$ molecular sieve. Pyridine was refluxed over $\mathrm{KOH}$, distilled and stored with activated Klinosorb $4 \AA$ molecular sieve. Triethylamine was purchased from Aldrich and refluxed 2 hours over calcium hydride prior to use. 2,6-Diaminopyridine was purchased from Aldrich and recrystallized in hot chloroform. Approximately $6 \mathrm{~g}$ drying agent per $1 \mathrm{~L}$ solvent were used in the drying processes. Potassium carbonate was purchased from Merck and dried at $105^{\circ} \mathrm{C}$ under vacuo prior to use. Benzylidenebis(tricyclohexylphosphine)dichlororuthenium (Grubbs 1st generation catalyst), thionylchloride, 1,6-dibromo hexane, furan, maleimide, tetrabromomethane, bromotris (triphenlyphosphine)copper(I), tetrakis(acetonitrile) hexafluorophosphate copper(I), ethyl vinyl ether, and sodiumborohydride were purchased from Aldrich and used as received. Triphenylphosphine (Merck) and sodium azide (Baker) were used as received. Trioctylphosphine oxide (TOPO) (technical grade (90\%)), trioctylphosphine (TOP), tributylphosphine (TBP), Hexadecylamine (HAD) (technical grade $(90 \%)$ ), selenium powder ( -100 mesh, $99.5+\%)$, cadmium oxide $(99,99+\%)$, tetrachlorauric(III) acid hydrate (99,999\%), allylic alcohol (99\%), AIBN (98\%) were purchased from Sigma-Aldrich. 5-Nitroisophthalic acid, Ndiisopropyl ethyl amine, 5-hexynoic acid, and oxalylchloride were purchased from Fluka. Tetradecylphosphonic acid $(99,5 \%)$ and dodecylphosphonic acid were purchased from Alfa-Aesar.

${ }^{1} \mathrm{H}$ and ${ }^{13} \mathrm{C}$ spectra were recorded at room temperature on a Bruker AC-E-200 $(200 \mathrm{MHz})$ and a Bruker Avance DRX-400 (400 MHz) FT-NMR spectrometer. $\mathrm{CDCl}_{3}$ (Isotec Inc. 99.8 atom $\% \mathrm{D})$ and DMSO- $d_{6}\left(\mathrm{HDO}+\mathrm{D}_{2} \mathrm{O}<0.02 \%\right)$ were used as solvents. Chemical shifts were recorded in "parts per million" (ppm) $(\delta)$ and referenced to residual protonated solvent $\left(\mathrm{CDCl}_{3}: 7.26 \mathrm{ppm}\left({ }^{1} \mathrm{H}\right)\right.$ and $77.0 \mathrm{ppm}$ $\left({ }^{13} \mathrm{C}\right)$; DMSO- $d_{6}: 2.54 \mathrm{ppm}\left({ }^{1} \mathrm{H}\right)$ and $\left.40.45 \mathrm{ppm}\left({ }^{13} \mathrm{C}\right)\right)$. Interpretation of the spectra- ${ }^{13} \mathrm{C}-\mathrm{NMR}$ : carbon atoms were listed in descending order starting from the highest; ${ }^{1} \mathrm{H}$ NMR: hydrogen atoms were listed in descending order starting from the highest using standard abbreviations for their coupling patterns $(\mathrm{s}=$ singlet, $\mathrm{d}=$ doublet, $\mathrm{t}=$ triplet, $\mathrm{q}$ = quadruplet, $\mathrm{m}=$ multiplet, $\mathrm{bs}=$ broad singlet ) .

Thin layer chromatography (TLC) was performed with coated glass plates of the type Sil G-25- $\mathrm{UV}_{254}$ obtained from Macherey-Nagel. As oxidation reagents a solutions of molybdato phosphoric acid (1.5 mg molybdato phosphoric acid in $100 \mathrm{~mL}$ ethanol), anisaldehyde (1 mL anisaldehyde, $2 \mathrm{~mL}$ concentrated sulphuric acid in $100 \mathrm{~mL}$ concentrated acetic acid), and cerium ammoniumnitrate solution ( $1 \mathrm{~g}$ cerium sulfate, $2.5 \mathrm{~g}$ ammoniumhepta molybdate, $6 \mathrm{~mL}$ concentrated sulphuric acid, $94 \mathrm{~mL}$ water) were used.

GPC spectra were recorded on a Hewlett Packard Series 1100 Chemstation system using Waters Styragel linear columns HR0.5, HR3, and HR4 in THF at $40^{\circ} \mathrm{C}$. Polystyrene 


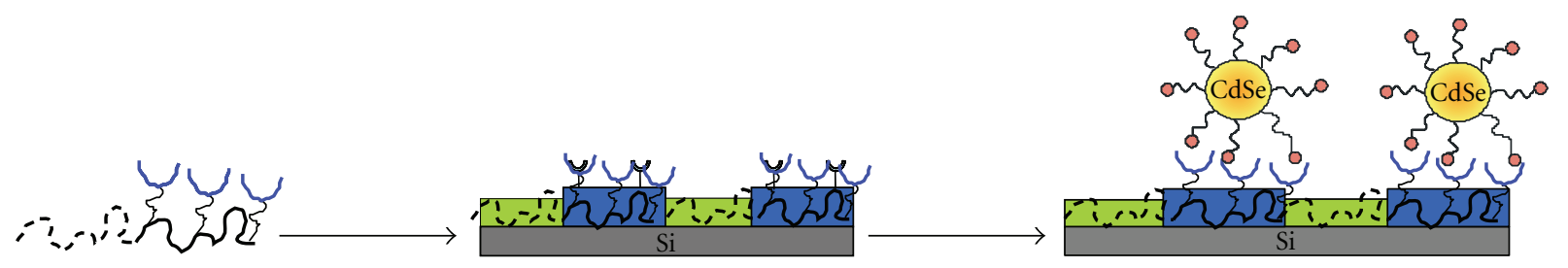

(a)

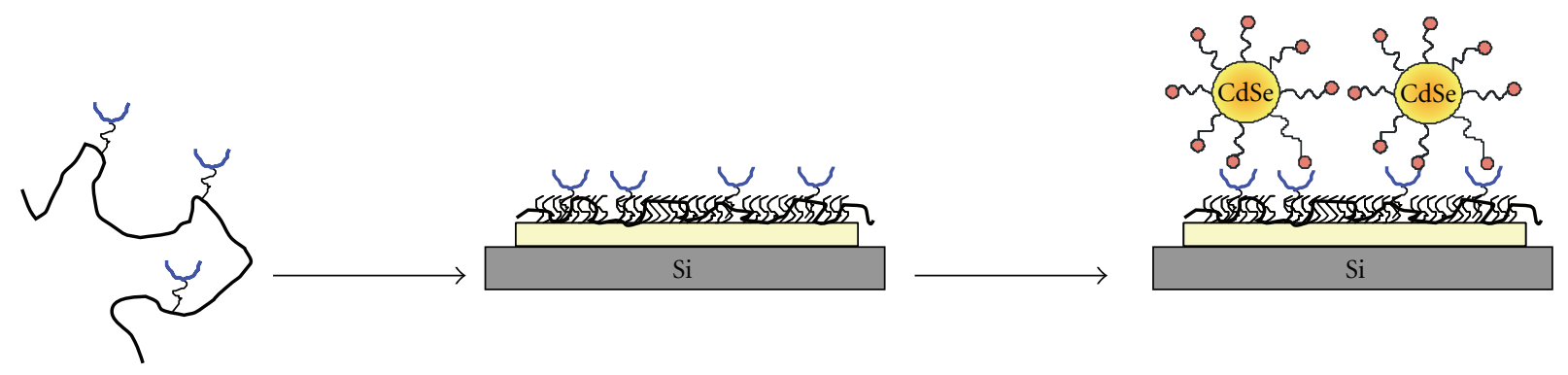

(b)

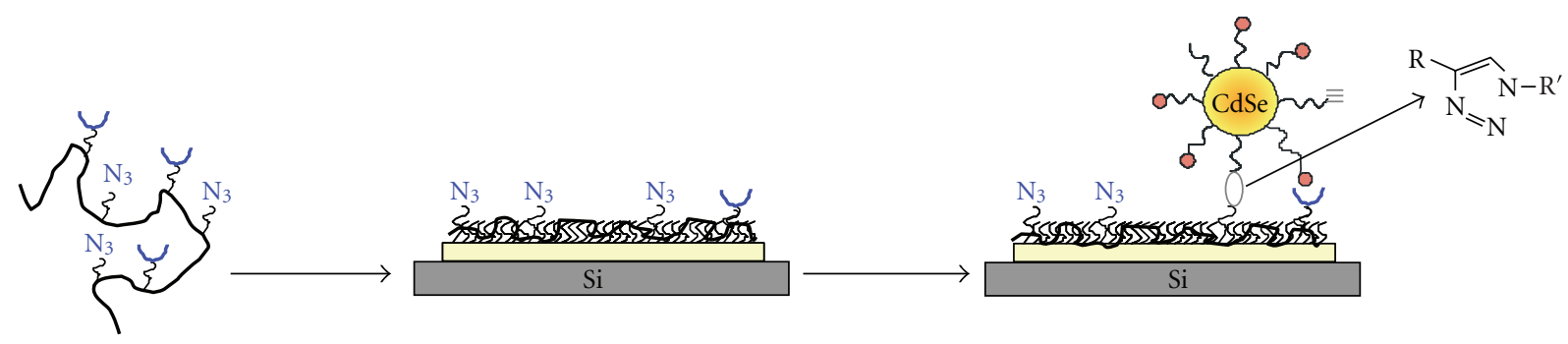

(c)
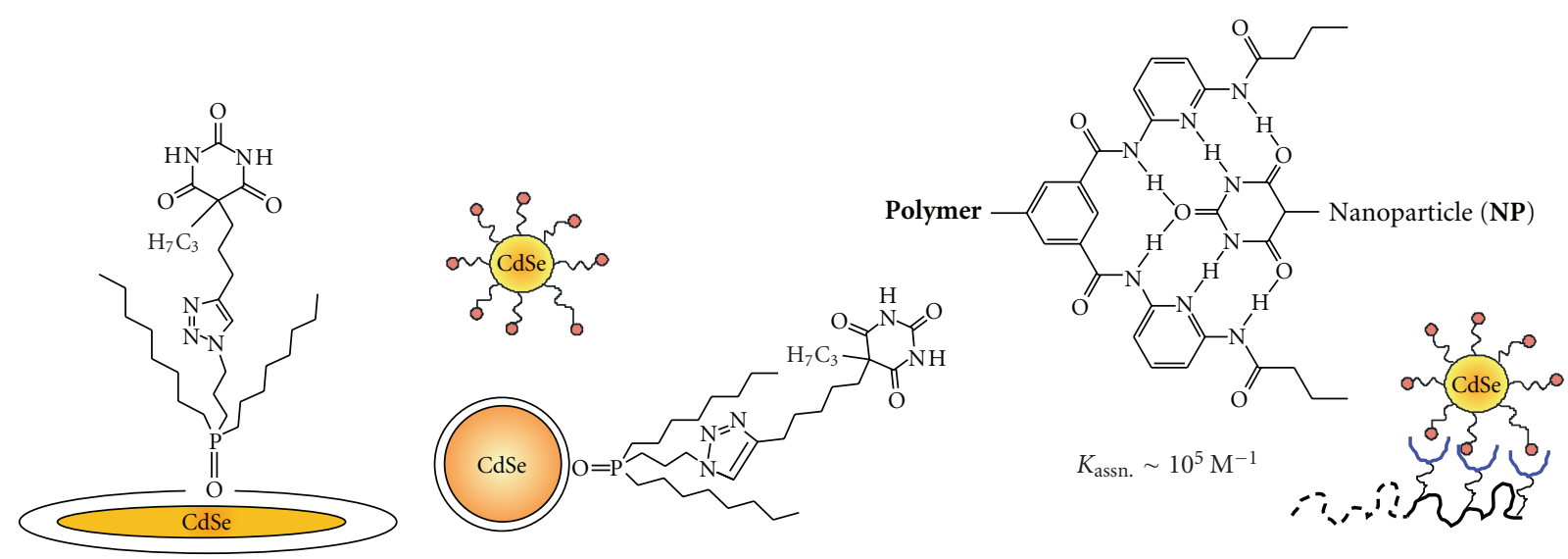

(d)

FIGURE 1: Schematic concept for the reversible and irreversible binding of nanoparticles to polymeric surfaces (a) film formation of block copolymers and reversible nanoparticle-binding. (b) film-formation of statistical copolymers and reversible nanoparticle binding. (c) irreversible attachment of nanoparticles onto polymer films by first supramolecular recognition and second azide/alkine-“click"-reaction. (d) Chemical structure of the used CdSe-nanoparticles and nanorods.

standards $\left(M_{p}=580-48840 \mathrm{~g} / \mathrm{mol}\right)$ were used for conventional external calibration using a Waters RI 2410 refractive index detector.

IR measurements were performed on a Biroad FTS-135 FT-IR spectrometer.

AFM Measurement. For the AFM investigations a NanoScope III multimode SPM from Digital Instruments,
Veeco Metrology Group, Santa Barbara, CA, has been used. Measurements were performed in tapping mode under ambient air using single-crystal silicon cantilevers (Arrow NC cantilevers, NanoWorld, Switzerland, spring constant $42 \mathrm{~N} / \mathrm{m}$, resonance frequency $\sim 285 \mathrm{kHz})$. Scanning was accomplished with an E-scanner (maximum scan range $10 \mu \mathrm{m} \times 10 \mu \mathrm{m})$ operated at a scanning rate of 2 and 
$4 \mathrm{~Hz}$, respectively, and an image resolution of $512 \times 512$ pixels. Data evaluation was performed with the NanoScope software version 6.13r1 (Digital Instruments, Veeco). The roughness data used in this paper are root-mean-square (rms) values, derived as standard deviations of all height values in an image. Phase images (i.e., the phase lag between the piezo-oscillation driving the AFM cantilever and its response) have been recorded simultaneously with the topographic images through the second data channel of the instrument. The used Si-wafers were provided by Wacker Siltronic.

DLS measurements were performed in toluene solutions of the NPs after dilution by $\sim 1 / 50$ with pure solvent on an ALV/CGS-3 compact goniometer using the ALV-5000/E correlator software.

TEM measurements were achieved on a Phillips EM300 transmission mode $100 \mathrm{kV}$. The nanorod solution (under high dilution of $\sim 1 / 50$ ) was applied on standard TEMGrids (300 mesh copper carbon only $(50 \mathrm{ct})$ ) purchased from Electron Microscopy Sciences.

2.1. Synthesis of Bromo Functionalized Statistic Copolymers (Polymer1s5). In a dry beaded rim bottle which was thoroughly flushed with argon, a solution of $200 \mathrm{mg}$ of exo-N-(4,4,5,5,6,6,7,7,7-nonafluoro-heptyl)-10-oxa4-aza-tricyclo-dec-8-ene-3,5-dione $\quad(1 a) \quad\left[\begin{array}{lll}18, & 28,29]\end{array}\right.$ and $1.6 \mathrm{mg}$ of exo-N-(6-bromo-hexyl)-10-oxa-4-azatricyclo-dec-8-ene-3,5-dione $(1 b)[18,28,29]$ in dry and deoxygenated dichloromethane $(10 \mathrm{ml})$ was prepared. A solution of benzylidene-bis(tricyclohexylphosphine) dichlororuthenium (Grubbs-1st-generation) in dichloromethane $(1 \mathrm{~mL})$ was added quickly to the reaction solution, which was stirred vigorously for 50-60 minutes. After complete monomer conversion (as monitored by TLC) the reaction mixture was quenched with ethyl vinyl ether and the crude polymer was evaporated to dryness. Precipitating twice from dichloromethane in methanol yielded bromo functionalized statistic copolymers (polymer 1s5) as a light brown solid. ${ }^{1} \mathrm{H}-\mathrm{NMR}\left(200 \mathrm{MHz}, \mathrm{CDCl}_{3}\right): \delta(\mathrm{ppm})=6.08$ (bs, $\mathrm{CH}_{2}=\mathrm{CH}_{2}$, trans), 5.80 (bs, $\mathrm{CH}_{2}=\mathrm{CH}_{2}$, cis), 5.03 (bs, $\mathrm{CH}-\mathrm{O}-\mathrm{CH}$, cis), 4.46 (bs, $\mathrm{CH}-\mathrm{O}-\mathrm{CH}$, trans), 3.70-3.20 (m, $\mathrm{CH}-\mathrm{C}=\mathrm{O}, \mathrm{N}-\mathrm{CH}_{2}, \mathrm{CH}_{2}-\mathrm{Br}$ ), 2.30-1.70 (m, alkyl), 1.65-1.20 $\left(\mathrm{m}\right.$, alkyl). ${ }^{13} \mathrm{C}-\mathrm{NMR}\left(50 \mathrm{MHz}, \mathrm{CDCl}_{3}\right): \delta(\mathrm{ppm})=175.7$, $130.8,122.0-107.0$ (multiplets, $\mathrm{J}_{\mathrm{FC}}^{1}=98 \mathrm{~Hz}, \mathrm{~J}_{\mathrm{FC}}^{2}=22 \mathrm{~Hz}$ ), 81.0, 53.4, 52.3, 38.7, 33.6, 32.5, 28.3 (triplet, $\mathrm{J}_{\mathrm{FC}}^{2}=22 \mathrm{~Hz}$ ), $27.6,27.5,25.9,18.9$.

2.2. Synthesis of Bromo Functionalized Block Copolymer (Polymer1b/1, 2, 5). In a round bottomed flask which was thoroughly flushed with argon, a solution of exo-N(4,4,5,5,6,6,7,7,7-nonafluoro-heptyl)-10-oxa-4-aza-tricyclodec-8-ene-3,5-dione $(1 a)$ in dry and deoxygenated dichloromethane $(10 \mathrm{~mL})$ was prepared. A solution of benzylidene-bis(tricyclohexylphosphine)dichlororuthenium (Grubbs-1st-generation) in dichloromethane $(10 \mathrm{ml})$ was added quickly to the reaction solution, which was stirred vigorously for $\sim 25$ minutes. After complete conversion of monomer (1a) (as monitored by TLC) a solution of
exo-N-(6-bromo-hexyl)-10-oxa-4-aza-tricyclo-dec-8-ene-3, 5 -dione $(1 b)$ in dichloromethane $(7 \mathrm{~mL})$ was transferred to the polymerization mixture, which again was stirred for another 25 minutes. After complete conversion of the second monomer (TLC monitoring) the living polymer chain end was quenched with $0.1 \mathrm{~mL}$ ethyl vinyl ether. The crude polymer was evaporated to dryness and precipitated twice from dichloromethane in methanol yielding polymer $1 / b 1$, 2, 5 as a light brown solid. ${ }^{1} \mathrm{H}-\mathrm{NMR}\left(200 \mathrm{MHz}, \mathrm{CDCl}_{3}\right): \delta$ $(\mathrm{ppm})=6.07\left(\mathrm{~s}, \mathrm{CH}_{2}=\mathrm{CH}_{2}\right.$, trans), $5.80\left(\mathrm{~s}, \mathrm{CH}_{2}=\mathrm{CH}_{2}\right.$, cis), 5.04 (s, CH-O-CH, cis), 4.46 (s, CH-O-CH, trans), 3.55 (s, br), 3.48(s, br), 3.40 (t, $\left.\mathrm{CH}_{2}-\mathrm{Br}\right), 3.33$ (s, br), 2.25-1.70 (m, alkyl), $1.70-1.10$ (m, alkyl). ${ }^{13} \mathrm{C}-\mathrm{NMR}\left(50 \mathrm{MHz}, \mathrm{CDCl}_{3}\right): \delta$ $(\mathrm{ppm})=175.5,131.9,130.9,121.5-105.0$ (multiplets, $\mathrm{J}_{\mathrm{CF}}^{1}$, $\mathrm{J}_{\mathrm{CF}}^{2}$ ), 81.0, 53.4, 52.3, 38.7, 37.9, 33.6, 32.5, 28.4 (triplett, $\left.\mathrm{J}_{\mathrm{CF}}^{2}\right), 27.6,25.9,18.9$.

2.3. General Procedure for the Synthesis of Azide Functionalized Copolymers (Polymer 2). Sodium azide was added to a solution of statistical copolymers (polymer 1s5, polymer $1 \mathrm{~b} / 2$, polymer $1 b / 1$, or polymer $1 b / 5)$ in dry DMF $(10 \mathrm{~mL})$ and the reaction was stirred for 6-8 hours at room temperature. The solvent was completely removed under reduced pressure, the residue was resuspended in $\mathrm{CHCl}_{3}$, filtrated through a syringe filter, concentrated and evaporated to dryness, yielding azide functionalized copolymers as light brown solids. All azide functionalized polymers have to be stored at $-20^{\circ} \mathrm{C}$. statistical copolymer polymer $2 / s 5:{ }^{1} \mathrm{H}-\mathrm{NMR}$ $\left(200 \mathrm{MHz}, \mathrm{CDCl}_{3}\right): \delta(\mathrm{ppm})=6.08$ (bs, $\mathrm{CH}_{2}=\mathrm{CH}_{2}$, trans), 5.79 (bs, $\mathrm{CH}_{2}=\mathrm{CH}_{2}$, cis), 5.02 (bs, $\mathrm{CH}-\mathrm{O}-\mathrm{CH}$, cis), 4.45 (bs, $\mathrm{CH}-\mathrm{O}-\mathrm{CH}$, trans), 3.70-3.20 (m, $\mathrm{CH}-\mathrm{C}=\mathrm{O}, \mathrm{N}-\mathrm{CH}_{2}$, $\mathrm{CH}_{2}-\mathrm{N}_{3}$ ), 2.30-1.75 (m, alkyl), $1.70-1.20$ (m, alkyl). ${ }^{13} \mathrm{C}-$ $\operatorname{NMR}\left(50 \mathrm{MHz}, \mathrm{CDCl}_{3}\right): \delta(\mathrm{ppm})=175.5,130.8,122.0-107.0$ (multiplets, $\mathrm{J}_{\mathrm{FC}}^{1}=98 \mathrm{~Hz}, \mathrm{~J}_{\mathrm{FC}}^{2}=22 \mathrm{~Hz}$ ), 82.2, 80.9, 53.3, 52.2, 51.1, 38.7, 28.6, 27.4, 26.2, 26.1, 18.9. block copolymer data: (polymer 2b/1, 2, 5) : ${ }^{1} \mathrm{H}-\mathrm{NMR}\left(200 \mathrm{MHz}, \mathrm{CDCl}_{3}\right): \delta$ $(\mathrm{ppm})=6.08$ (bs, $\mathrm{CH}_{2}=\mathrm{CH}_{2}$, trans), 5.79 (bs, $\mathrm{CH}_{2}=\mathrm{CH}_{2}$, cis), 5.02 (bs, CH-O-CH, cis), 4.45 (bs, $\mathrm{CH}-\mathrm{O}-\mathrm{CH}$, trans), 3.70-3.20 (m, CH-C=O, N- $\left.\mathrm{CH}_{2}, \mathrm{CH}_{2}-\mathrm{N}_{3}\right), 2.30-1.75(\mathrm{~m}$, alkyl), $1.70-1.20\left(\mathrm{~m}\right.$, alkyl). ${ }^{13} \mathrm{C}-\mathrm{NMR}\left(50 \mathrm{MHz}, \mathrm{CDCl}_{3}\right): \delta$ $(\mathrm{ppm})=175.5,130.8,122.0-107.0$ (multiplets, $\mathrm{J}_{\mathrm{FC}}^{1}=98 \mathrm{~Hz}$, $\left.\mathrm{J}_{\mathrm{FC}}^{2}=22 \mathrm{~Hz}\right), 82.2,80.9,53.3,52.2,51.1,38.7,28.6,27.4,26.2$, $26.1,18.9$.

2.4. General Procedure for the Synthesis of Statistic Copolymers that Exhibit Hamilton Receptor Functionalities (Polymer 3). A solution of azide functionalized statistic copolymers (polymer 2s1-5), 5-hex-5-ynoylamino-N,N' ${ }^{\prime}$-bis-(6octanoylamino-pyridin-2-yl)-isophthalamide (2), [18, 28, 29] tetrakis(acetonitrile) hexafluorophosphate copper(I), TBTA and N,N-diisopropylethylamine in a solvent mixture of deoxygenated DMF $(6 \mathrm{~mL})$, toluene $(1.5 \mathrm{~mL})$, and water $(0.1 \mathrm{~mL})$ was stirred at ambient temperature for 48 hours. The reaction mixture was evaporated to dryness and precipitated twice from dichloromethane in methanol, yielding Hamilton receptor functionalized polymer 3, as brown solids. Statistical copolymer polymer 3s/5: ${ }^{1} \mathrm{H}-\mathrm{NMR}(200 \mathrm{MHz}$, $\left.\mathrm{CDCl}_{3}\right): \delta(\mathrm{ppm})=6.07(\mathrm{~s}, 1.4 \mathrm{H}$, trans $), 5.81(\mathrm{~s}, 0.6 \mathrm{H}, \mathrm{cis})$, 

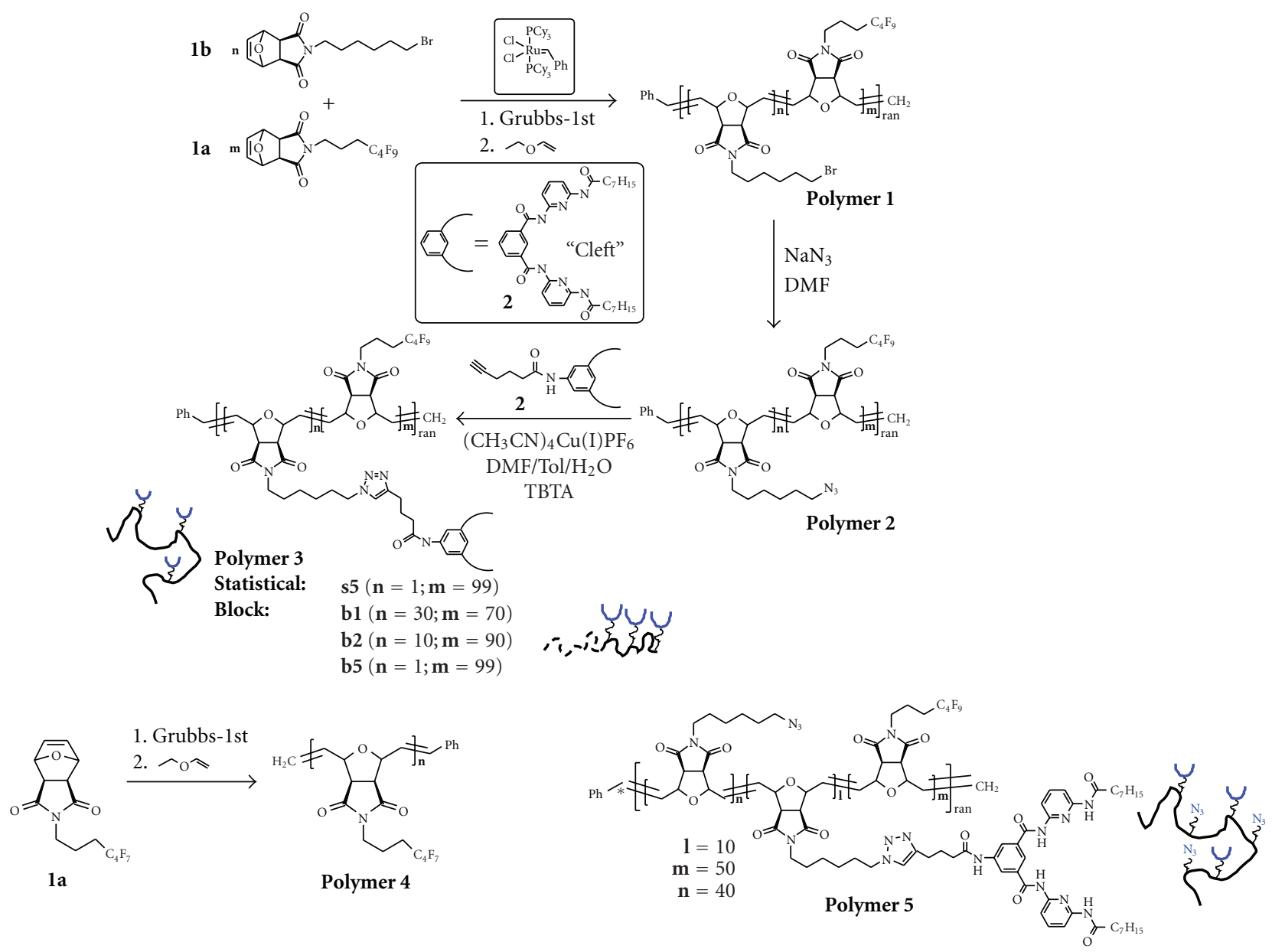

Scheme 1: Chemical structure and synthesis of the polymers 1-4 and polymer 5.

5.04 (s, $0.4 \mathrm{H}$, cis), 4.44 (s, 1.6H, trans), 3.57 (bs, $2 \mathrm{H}), 3.34$ (bs, $2 \mathrm{H}), 2.30-1.80(\mathrm{~m}, 4 \mathrm{H}) .{ }^{13} \mathrm{C}-\mathrm{NMR}\left(50 \mathrm{MHz}, \mathrm{CDCl}_{3}\right): \delta$ $(\mathrm{ppm})=175.4,130.8,122.0-107.0$ (multiplets, $\mathrm{J}_{\mathrm{FC}}^{1}=98 \mathrm{~Hz}$, $\left.\mathrm{J}_{\mathrm{FC}}^{2}=22 \mathrm{~Hz}\right), 82.2,80.8,53.4,52.2,37.9,28.6\left(\mathrm{t}, \mathrm{J}_{F C}^{2}=22 \mathrm{~Hz}\right)$, 19.0. block copolymer data: (polymer $3 b / 1,2,5):{ }^{1} \mathrm{H}-\mathrm{NMR}$ $\left(200 \mathrm{MHz}, \mathrm{CDCl}_{3}\right): \delta(\mathrm{ppm})=6.07(\mathrm{~s}, 1.4 \mathrm{H}$, trans $), 5.81(\mathrm{~s}$, $0.6 \mathrm{H}$, cis), 5.04 (s, 0.4H, cis), 4.44 (s, 1.6H, trans), 3.57 (bs, $2 \mathrm{H}), 3.34$ (bs, $2 \mathrm{H}), 2.30-1.80(\mathrm{~m}, 4 \mathrm{H}) .{ }^{13} \mathrm{C}-\mathrm{NMR}(50 \mathrm{MHz}$, $\left.\mathrm{CDCl}_{3}\right): \delta(\mathrm{ppm})=175.4,130.8,122.0-107.0$ (multiplets, $\mathrm{J}_{\mathrm{FC}}^{1}$ $\left.=98 \mathrm{~Hz}, \mathrm{~J}_{\mathrm{FC}}^{2}=22 \mathrm{~Hz}\right), 82.2,80.8,53.4,52.2,37.9,28.6\left(\mathrm{t}, \mathrm{J}_{\mathrm{FC}}^{2}\right.$ $=22 \mathrm{~Hz}$ ), 19.0 .

2.5. Synthesis of Statistic Copolymers that Exhibit Azide and Hamilton Receptor Functionalities (Polymer 5). A solution of an azide functionalized statistic copolymers (polymer2s with $n=50 ; m=50$ ) (239 mg), 5-hex-5ynoylamino-N, N' -bis-(6-octanoylamino-pyridin-2-yl)-isophthalamide (2) [30] (40 mg), tetrakis(acetonitrile) hexafluorophosphate copper(I) (15 mg), TBTA (17 mg) and $\mathrm{N}, \mathrm{N}$-diisopropylethylamine $(0.22 \mathrm{~mL})$ in a solvent mixture of deoxygenated DMF $(6 \mathrm{~mL})$, toluene $(1.5 \mathrm{~mL})$ and water $(0.1 \mathrm{~mL})$ was stirred at ambient temperature for 48 hours. The reaction mixture was evaporated to dryness and precipitated twice from dichloromethane in methanol, yielding polymer 5 as brown solids. Yield: $231 \mathrm{mg}$. GPC data: $M_{n}=34175 \mathrm{Da} ; M_{w}=37024 \mathrm{Da}$; PDI $=1,1^{1} \mathrm{H}-\mathrm{NMR}$ $\left(200 \mathrm{MHz} \mathrm{CDCl}_{3}\right): \delta(\mathrm{ppm})=6.07$ (s, 1.4H, trans), 5.81 (s, $0.6 \mathrm{H}$, cis), 5.04 ( $\mathrm{s}, 0.4 \mathrm{H}$, cis), 4.44 ( $\mathrm{s}, 1.6 \mathrm{H}$, trans), 3.57 (bs, 2H), 3.34 (bs, 2H), 2.30-1.80 (m, 4H), 1.70-1.20 (m, alkyl). ${ }^{13} \mathrm{C}-\mathrm{NMR}\left(50 \mathrm{MHz}, \mathrm{CDCl}_{3}\right): \delta(\mathrm{ppm})=175.4,130.8$, 122.0-107.0 (multiplets, $\mathrm{J}_{\mathrm{FC}}^{2}=98 \mathrm{~Hz}, \mathrm{~J}_{\mathrm{FC}}^{2}=22 \mathrm{~Hz}$ ), 82.2, 80.8, $53.4,52.2,51.1,37.9,28.6\left(\mathrm{t}, \mathrm{J}_{\mathrm{FC}}^{2}=22 \mathrm{~Hz}\right), 27.4,26.1,19.0$.

2.6. Synthesis of Homo Polymers (Polymer 4). In a drybeaded rim bottle which was thoroughly flushed with argon a solution of exo-N-(4,4,5,5,6,6,7,7,7-nonafluoro-heptyl)10-oxa-4-aza-tricyclo-dec-8-ene-3,5-dione (1a) (200 mg, $0.470 \mathrm{mmol}$ ) in dry and deoxygenated dichloromethane $(10 \mathrm{~mL})$ was prepared. A solution of benzylidenebis(tricyclohexylphosphine) dichlororuthenium (Grubbs1st-generation) (3.9 mg, $0.0047 \mathrm{mmol}$ ) in dichloromethane $(10 \mathrm{~mL})$ was added quickly to the reaction solution, which was stirred vigorously. After complete monomer conversion (as monitored by TLC) the reaction mixture was quenched with ethyl vinyl ether $(0.1 \mathrm{~mL})$ and the crude polymer was evaporated to dryness, precipitated twice from 


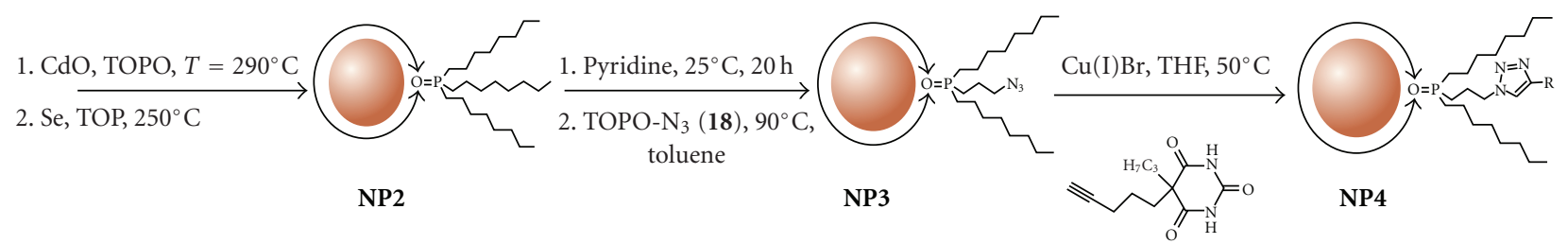

(a)

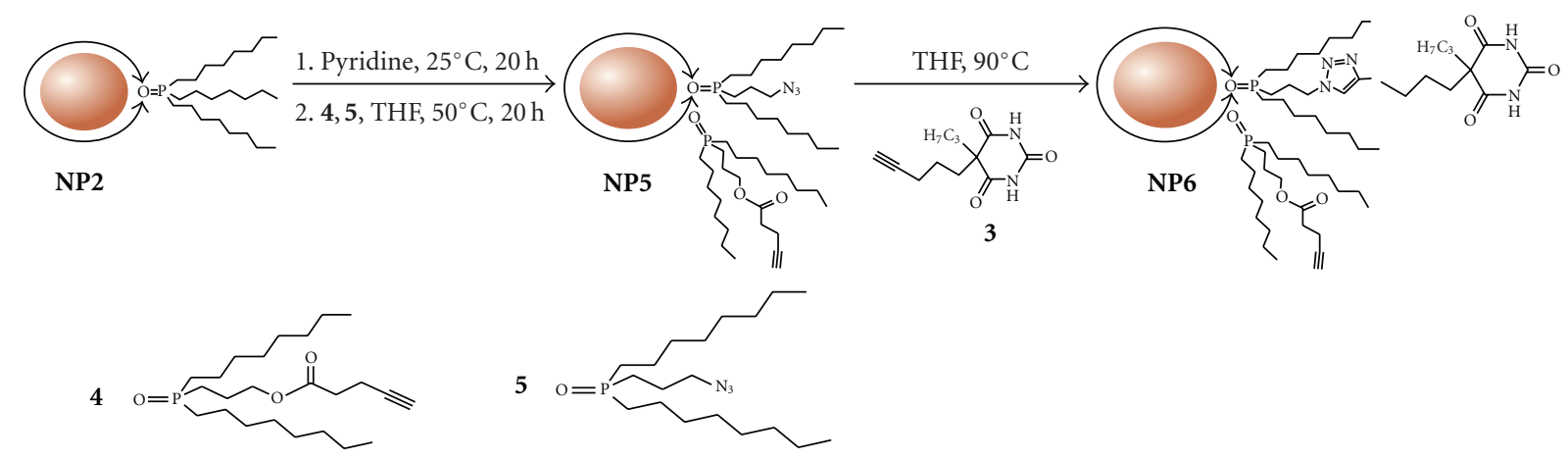

(b)

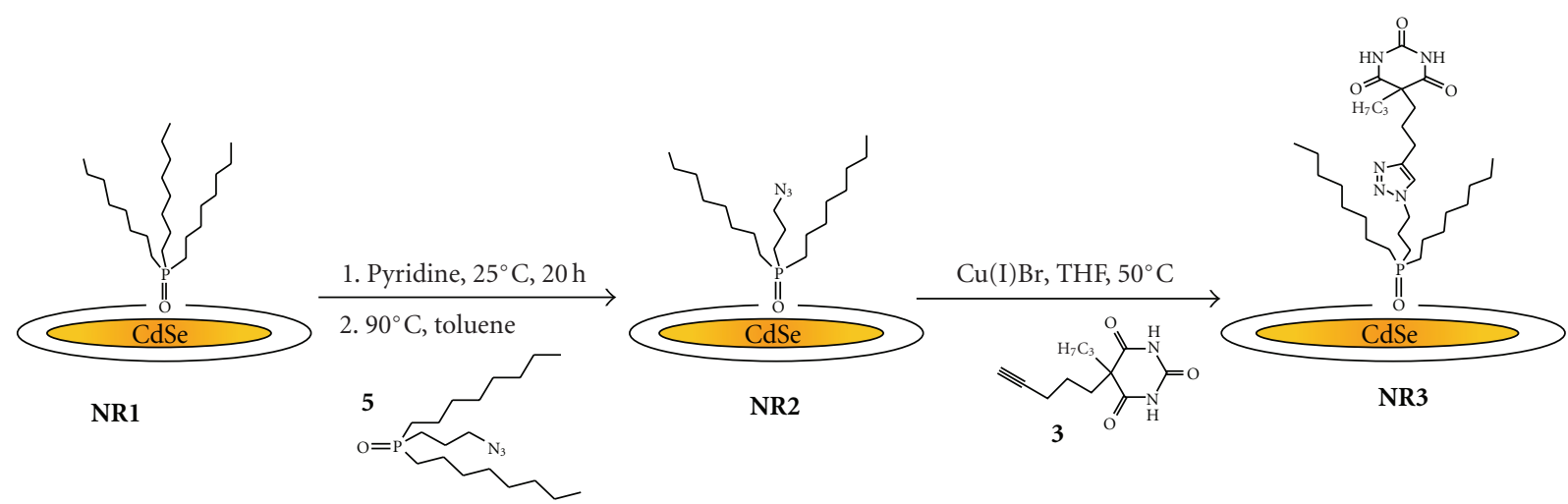

(c)

Figure 2: Synthesis of (a) CdSe-nanoparticles with barbituric acid ligands on their surface (NP4); (b) nanoparticles with partially covered surfaces, constisting of barbituric acid ligands and pendant alkine-moieties (NP6); (c) CdSe-nanorods with pendant barbituric acid moieties (NR3).

dichloromethane in methanol to yield polymer4 as light brown solid. Yield: $200 \mathrm{mg}$. GPC data: $M_{n}$ : $32523 \mathrm{Da}$, $M_{w}: 34713 \mathrm{Da}$, PDI: $1,07 .{ }^{1} \mathrm{H}-\mathrm{NMR}\left(200 \mathrm{MHz}, \mathrm{CDCl}_{3}\right): \delta$ $(\mathrm{ppm})=6.07(\mathrm{~s}, 1.4 \mathrm{H}$, trans $), 5.81(\mathrm{~s}, 0.6 \mathrm{H}, \mathrm{cis}), 5.04(\mathrm{~s}$, $0.4 \mathrm{H}$, cis), 4.44 (s, 1.6H, trans), 3.57 (bs, $2 \mathrm{H}$ ), 3.34 (bs, $2 \mathrm{H}$ ), 2.30-1.80 (m, 4H). ${ }^{13} \mathrm{C}-\mathrm{NMR}\left(50 \mathrm{MHz}, \mathrm{CDCl}_{3}\right): \delta(\mathrm{ppm})$ $=175.4,130.8,122.0-107.0$ (multiplets, $\mathrm{J}_{\mathrm{FC}}^{1}=98 \mathrm{~Hz}, \mathrm{~J}_{\mathrm{FC}}^{2}=$ $22 \mathrm{~Hz}), 80.8,53.4,52.2,37.9,28.6\left(\mathrm{t}, \mathrm{J}_{\mathrm{FC}}^{2}=22 \mathrm{~Hz}\right), 19.0$.

2.7. Synthesis of $\sim 5 \mathrm{~nm}$ CdSe Nanoparticles NP2 [31]. Cadmium oxide $(67.1 \mathrm{mg}, 0.523 \mathrm{mmol})$, TOPO $(2020 \mathrm{mg}$, $0.47 \mathrm{mmol}$ ) and HDA (3066 mg, $0.127 \mathrm{mmol}$ ) were heated to $270^{\circ} \mathrm{C}$ under argon atmosphere. At this temperature DDPA (273.6 mg, $1.1 \mathrm{mmol}$ ) was added and the temperature was increased to $290^{\circ} \mathrm{C}$. A solution consisting of Se $(92.8 \mathrm{mg}$, $1.18 \mathrm{mmol})$, TOP $(9.76 \mathrm{mmol}, 3618 \mathrm{mg})$, and dry toluene $(175 \mathrm{mg})$ was quickly added to the Cd-precursor solution at $290^{\circ} \mathrm{C}$ under strong stirring. Then temperature was quickly reduced to $250^{\circ} \mathrm{C}$ and the reaction solution was left at this temperature for 2 minutes. The growth of the nanoparticles was stopped by removing the reaction vessel from the heating source. The TOPO-nanoparticles NP2 were precipitated with dry methanol and stored in dry THF and toluene, respectively, in darkness and argon atmosphere.

2.8. Synthesis of CdSe Nanoparticles NP3. TOPO nanoparticles NP2 $(100 \mathrm{mg})$ were dissolved in $5 \mathrm{~mL}$ pyridine and stirred at room temperature for 20 hours. Most of the pyridine was removed to yield a viscous solution. The resulting pyridine-covered nanoparticles were then precipitated twice in $n$-hexane and centrifuged in order to remove all of the free TOPO-ligand. Subsequently, $350 \mathrm{mg}(0.98 \mathrm{mmol})$ of 1-[(3-azidopropyl)octylphosphinoyl] octane (DOPO- $\mathrm{N}_{3}$ ligand) 5 were added to a solution of the NPs in $5 \mathrm{~mL}$ of freshly distilled anhydrous THF and stirred for 20 hours at $50^{\circ} \mathrm{C}$. The THF was evaporated under reduced pressure and 


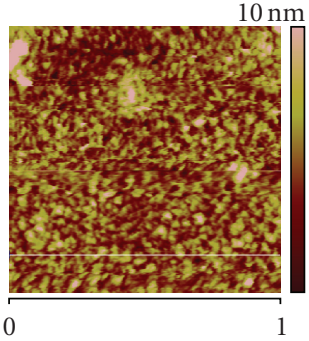

$(\mu \mathrm{m})$
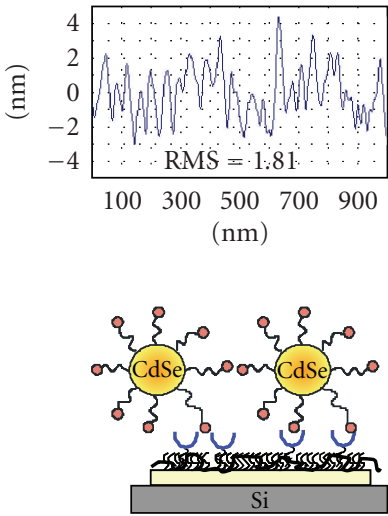

(a)

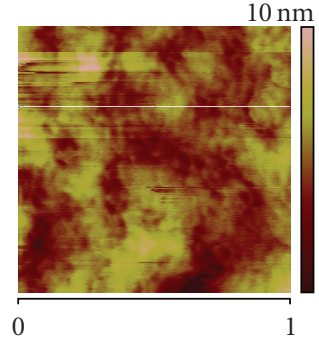

$(\mu \mathrm{m})$
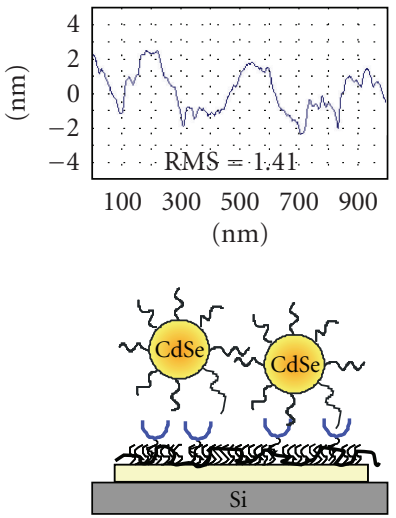

(b)

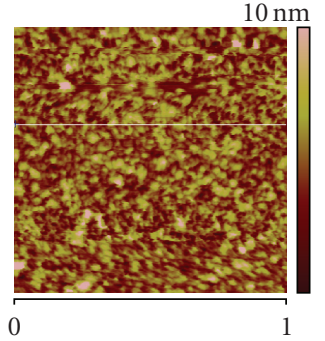

$(\mu \mathrm{m})$
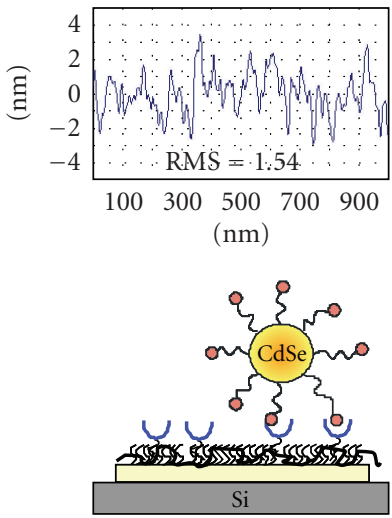

(c)

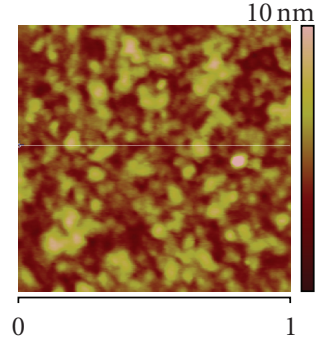

$(\mu \mathrm{m})$
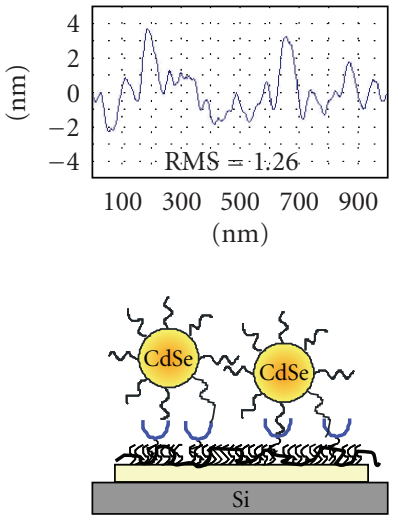

(d)

FIGURE 3: AFM-micrographs of attachment experiments of CdSe-nanoparticles to films made from statistical copolymers. (a) polymer 3/s5 ( $1 \mathrm{~mol} \%$ cleft) with NP4 (barbituric acid); (b) polymer 3/s5 (1 mol\% cleft) with NP2 (TOPO); (c) polymer 3/s7 (0.1 mol\% cleft) with NP4 (barbituric acid); (d) polymer $3 / \mathrm{s} 7$ (0.1 mol\% cleft) with NP2 (TOPO).

the nanoparticles (NP3) were precipitated twice in $20 \mathrm{~mL}$ anhydrous methanol to remove unattached ligands.

2.9. Synthesis of CdSe Nanoparticles NP5 [31]. TOPO nanoparticles NP2 $(250 \mathrm{mg})$ were dissolved in $5 \mathrm{~mL}$ pyridine and stirred at room temperature for 20 hours. Most of the pyridine was removed to yield a viscous solution. The resulting pyridine-covered nanoparticles were then precipitated in $\mathrm{n}$-hexane and centrifuged. The precipitation procedure was repeated twice in order to remove all of the free TOPO-ligands. Subsequently, DOPO- $\mathrm{N}_{3}$ (5) [31] (44 mg, $0.12 \mathrm{mmol}$ ) and hex-5-ynoic acid 3(dioctylphosphinoyl)propyl ester (DOPO-acetylene) (4), (53 mg, $0.12 \mathrm{mmol}$ ) [31] were added to a solution of the NPs in freshly distilled anhydrous THF and the stirring was continued for 20 hours at $50^{\circ} \mathrm{C}$. The THF was evaporated under reduced pressure and the nanoparticles (NP5) were precipitated twice in $20 \mathrm{~mL}$ anhydrous methanol to remove unattached ligands.

2.10. Synthesis of CdSe Nanoparticles NP4 and NP6. NP3 and NP5, respectively, (100 mg), 5-pent-4-inyl5-propyl-pyrimidin-2,4,6-trion 3 [30] $(0.112 \mathrm{mmol})$, DIPEA $(0.112 \mathrm{mmol})$, TBTA $(0.00112 \mathrm{mmol})$, and $\mathrm{Cu}(\mathrm{I}) \mathrm{Br}$ $(0.00112 \mathrm{mmol})$ were dissolved in $5 \mathrm{~mL}$ degassed anhydrous toluene and heated to $50^{\circ} \mathrm{C}$. After 10 hours THF was removed under reduced pressure and the resulting NP4 and NP6 were twice precipitated in $20 \mathrm{~mL}$ anhydrous methanol and stored in dry toluene in darkness under argon atmosphere.

2.11. Preparation of Smooth Polymerfilms Derived from Poly(Oxy-Norbornenes). Silicon wafers were cut in squares of $8 \times 8 \mathrm{~mm}$ using a glass cutter, cleaned from dust and silicon splinters with a stream of nitrogen and incubated into a dust-free ethanol solution (filtrated through a syringe filter) for 5-10 minutes. From this solution they were quickly taken out and immediately dried with a strong stream of nitrogen in order to prevent solvent margins obtained from evaporation. Subsequent UV-irradiation for 15 minutes completely oxidized the surface and removed the last organic impurities on the wafers, which was again followed by cleaning with nitrogen. All wafers were stored in small and clean glass/plastic jars until they were used for coating.

Polymer solutions $(0.5 \mathrm{wt} \%)$ were prepared directly before dip coating and stored in dust-free jar. Dip coating was performed on a static wafer which is dip coated by a downward moving $(3 \mathrm{~mm} / \mathrm{min})$ solution jar. In order to prepare polymerfilms via dip coating techniques the wafers were taken from the storage jar and cleaned by a strong stream of nitrogen. Then they were statically affixed with a tweezer using a metal tripod to place them correctly into the dip coating device. Then a jar containing a completely dustfree polymer solution (syringe filter) was attached onto the lifting arm of the dip coater and the dip coating sequence was started. Once the dip coating sequence is ended, the silicon 
wafers were cleaned by a stream of nitrogen, placed into a clean glass or plastic jar and stored under exclusion of light at $0^{\circ} \mathrm{C}$.

The prepared polymer films can be annealed subsequently. Therefore the wafers were taken from their storage jars, cleaned with a strong stream of nitrogen, and put into a $250 \mathrm{~mL}$ round-bottomed flask by carefully sliding them along the glass wall towards the bottom of the vessel. The flask was put in a preheated oil bath $\left(80^{\circ} \mathrm{C}\right)$, evacuated and the wafers were protected from light. After complete annealing ( $\sim 48$ hours), the wafers were allowed to cool and the vacuum was removed. The annealed polymer films were stored in a clean glass or plastic jar under exclusion of light at $0^{\circ} \mathrm{C}$.

In order to assemble nanoparticles or "clicking" different functionalities onto the polymer surface $0.3 \%$ solution of nanoparticle in toluene was prepared. The annealed polymerfilms on Si-wafer were put into nanoparticle solution and stored there for 16 hours. After complete incubation the silicon wafers were thoroughly cleaned with toluene and dried in a strong stream of nitrogen in order to prevent solvent margins obtained from evaporation and stored in a clean and dust-free jar under exclusion of light at $0^{\circ} \mathrm{C}$.

\section{Results and Discussion}

3.1. Polymers, Nanoparticles, Surfaces. Basic concept of the presented work is the use of the Hamiltonreceptor/barbiturate-interaction with an association constant of $K_{\text {assn. }} \sim 10^{5} \mathrm{M}^{-1}$, (as determined in nonpolar solvents, i.e, chloroform, dichloromethane, hexane), affixed to the sidechains of a poly(norbornene) which serves as scaffold for the presentation of the supramolecular interaction after film formation. As outlined in Figure 1, three basic principles of $\mathrm{CdSe}-\mathrm{NP} /$ nanorod binding towards these polymer surfaces are investigated: (a) reversible binding towards statistically distributed Hamilton-receptors within the polymer, (b) reversible binding towards blockydistributed Hamilton-receptors within the polymer, and (c) irreversible binding via first recognition and then irreversible fixation of the nanoparticles on the polymer surface. CdSe-nanoparticles (NPs) and-nanorods (NR) with either trioctylphosphineoxide (TOPO)-(NP2, NR1) or barbituric acid moieties (NP4, NR3) [31] have been used for the binding studies.

3.1.1. Preparation of Polymers. Polymers derived from poly(norbornenes) with defined amounts of Hamiltonreceptor within their chain were prepared via the ROMP/click-methodology described previously [28-30]. In brief (see Figure 2) the homo- or block copolymerization of the monomers $1 a, b$ furnishes polymer 1 (total degree of polymerization is $n+m=100$ ) bearing pendant bromine-moieties in amounts ranging from $1,10,30$, or $50 \mathrm{~mol} \%$ (Scheme 1). Quantitative transformation of the primary- $\mathrm{CH}_{2}-\mathrm{Br}$ moieties furnishes the $\mathrm{CH}_{2}-\mathrm{N}_{3}$-moieties quantitatively, which subsequently are transformed into

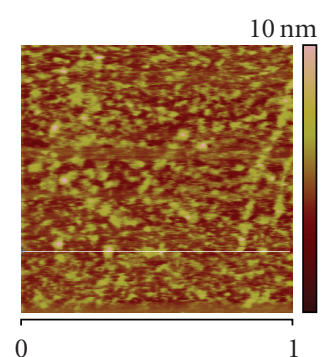

$(\mu \mathrm{m})$
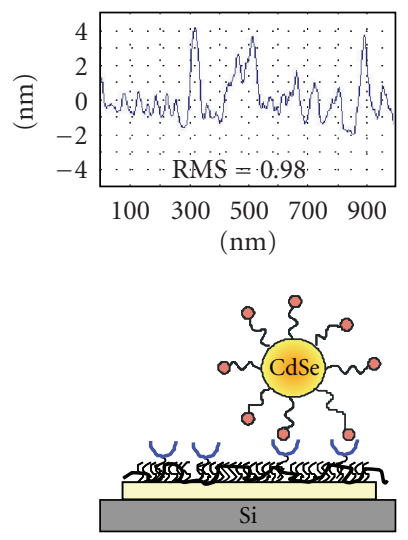

(a)

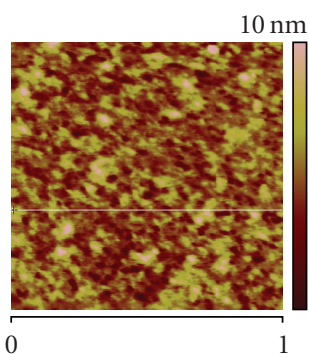

$(\mu \mathrm{m})$
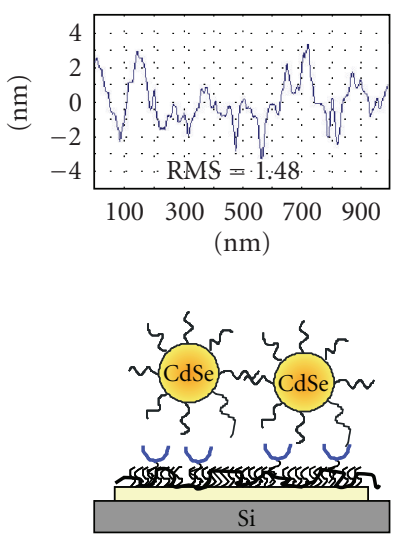

(b)
FIGURE 4: AFM-micrographs of attachment experiments of CdSenanoparticles to films made from statistical copolymers. (a) polymer $3 / \mathrm{s} 8$ (0.01 mol\% cleft) with NP4 (barbituric acid); (b) polymer $3 / \mathrm{s} 8$ (0.01 mol\% cleft) with NP2 (TOPO).

the affixed Hamilton-receptors via azide/alkine-"click"reactions, furnishing polymer 3 either as statistical or block structures with molar percentages of the Hamilton receptor ranging from $1-50 \mathrm{~mol} \%$ [28]. Data of the polymers are shown in Table 1, revealing low polydispersities and wellmatching molecular weights of polymers 1 and polymer 3. Since lower percentages of the Hamilton-receptor cannot be obtained by direct copolymerization, they were prepared by stoichiometrical mixtures of polymer 3/s5 with a perfluorinated homopolymer (polymer 4). This leads to the generation of molar percentages of Hamiltonreceptor down to $0.01 \mathrm{~mol} \%$. Furthermore, a polymer with pendant Hamilton-receptor and pendant azide-moieties was prepared (polymer 5), serving as scaffold for the subsequent nanoparticle-attachment experiment. To this purpose, polymer 5 was prepared starting from a 50/50 mixture of monomer $1 a, 1 b$, which was reacted into the corresponding azides as described before. Subsequent reaction with a substoichiometric amount of Hamilton-receptor 2 furnished polymer 5 quantitatively within this "click"-reaction, yielding polymer 5 with the following composition: (10 mol\% cleft, $40 \mathrm{~mol} \%$ azide-moieties). The presence of the residual azidemoieties is proven by IR- and NMR-spectroscopy. Details are described in the experimental and the supplementary.

3.1.2. Preparation of Nanoparticles and Nanorods. CdSenanoparticles (sized $5 \mathrm{~nm}$ ) were prepared analogous to 
TABLe 1: Physical properties of statistical and block copolymers.

\begin{tabular}{|c|c|c|c|c|c|c|c|c|c|c|c|}
\hline Polymer 1 & & $n$ & $m$ & Yield [\%] & $M_{n, \text { th }}$ & $M_{n}$ & $M_{w}$ & $M_{w} / M_{n}$ & Polymer 3 & $M_{n}$ & $M_{w} / M_{n}$ \\
\hline Statistical & s5 & 1 & 99 & 99 & 42532 & 37900 & 41380 & 1.1 & $s 5$ & 38630 & 1.1 \\
\hline Block & $b 1$ & 30 & 70 & 97 & 39740 & 28450 & 31920 & 1.1 & $b 1$ & 49210 & 1.2 \\
\hline Block & $b 2$ & 10 & 90 & 97 & 41659 & 25840 & 26980 & 1.1 & $b 2$ & 33030 & 1.1 \\
\hline Block & $b 5$ & 1 & 99 & 78 & 42532 & 27240 & 28600 & 1.1 & $b 5$ & 27960 & 1.1 \\
\hline Polymer 5/statistical & & 50 & 50 & 99 & 37813 & 34170 & 37020 & 1.1 & - & - & - \\
\hline Polymer 4/homo & & 0 & 100 & 99 & 42553 & 32520 & 34710 & 1.1 & - & 一 & - \\
\hline Polymer & $s 6$ & 0.5 & 99.5 & \multicolumn{4}{|c|}{ Prepared by mixing of polymer $3 / s 5$ with polymer $4(1: 1)$} & & & & \\
\hline Polymer & $s 7$ & 0.1 & 99.9 & \multicolumn{4}{|c|}{ Prepared by mixing of polymer $3 / s 5$ with polymer 4 (1:9) } & & & & \\
\hline Polymer & $s 8$ & 0.01 & 99.99 & \multicolumn{4}{|c|}{ Prepared by mixing of polymer $3 / s 5$ with polymer $4(1: 99)$} & & & & \\
\hline
\end{tabular}

a previously published method (Figure 2) [31], relying on the generation of trioctylphosphineoxide (TOPO)-CdSe$\mathrm{NP}$, ligand exchange by pyridine, ligand adsorption of the phosphineoxide-ligand 5 , and subsequent click-reaction (furnishing barbiturate-modified nanoparticles NP4. CdSenanorods (length: $20 \mathrm{~nm}$; diameter: $7 \mathrm{~nm}$ ) [32] were prepared in a similar manner, starting from TOPO-modifed CdSe-nanorods and a similar procedure of ligand-exchange and "click"-reactions. A special case involved the preparation of NP5, bearing attached babituric acid ligands and residual alkine groups. To this respect both ligands (namely ligands 4 and 5) were applied as an equimolar mixture, adsorbed to NP2, and reacted with the barbituric-acid-alkene. As proven by IR-spectroscopy (see supplementary), residual azide-moieties are present on the surface of NP6.

3.1.3. Reversible Nanoparticles Binding. Polymers were processed as thin films (thickness approx. $20 \mathrm{~nm}$, as determined by ellipsometry) on silicon wafers via dip coating from polymer solutions (approx. 0.5\% in tetrahydrofurane (THF). The presence of the fluorinated monomer $(1 a)$ was found to be crucial in obtaining thin homogeneous films as described previously [29]. After drying, the films were incubated with the respective nanoparticle solutions (in toluene or hexane).

As shown in Figures 3 and 4, the NP4 (with the barbiturate-ligand) bind strongly to the statistical polymer surfaces with $1 \mathrm{~mol} \%$ receptor (Figure $3(\mathrm{a})$, polymer $3 / s 5), 0.1 \mathrm{~mol} \%$ receptor (Figure 3(c), polymer 3/s7), and $0.01 \mathrm{~mol} \%$ receptor (see Figure $4(\mathrm{a})$, polymer $3 / \mathrm{s} 8$ ), with reduced amounts of nanoparticles with decreasing amount of supramolecular interaction. In order to probe nonspecific binding, also the noninteracting CdSe-NP2 (bearing a TOPO-ligand) were investigated.

As shown in Figures 3(b), 3(d), and 4(b), increased amount of nonspecific binding is observed, being absent in the presence of high supramolecular interactions and increasing when the amount of supramolecular interaction is reduced. This behavior can be explained by increasing nonpolar interactions between the TOPO-NP2 and the hydrocarbon-moieties of the statistical polymers with reduced amounts of polar (= supramolecular) interaction.

With block copolymers as scaffolds, the difference between specific and nonspecific binding in the case of
NP4 versus NP2 is less pronounced (see Figure 5). Thus the difference between specific and nonspecific binding is hardly visible (see comparison between Figures 5(a)/5(b) or Figures $5(\mathrm{c}) / 5(\mathrm{~d}))$. Due to the presence of both blocks in these relatively diluted block copolymers, polar and nonpolar regions are either too small to be discerned by the nanoparticles, or-alternatively - the polar regions of the block copolymer partially point towards the polar silicon wafer surface. Thus, statistical polymers are advantageous over block copolymers in terms of specificity and selectivity of the nanoparticle-binding process.

As the nanoparticles NP4 are bound via a hydrogen bond, its strength is dependent on the nature of the used solvent. Thus we have probed the detachment of the nanoparticles as shown in Figure 6, using methanol as solvent (24hour incubation). Since methanol is a nonsolvent for the polymer, it can be used to reduce the binding constant of the interaction between the Hamilton-receptor/barbituric acid-moieties from approx. $\sim 10^{5} \mathrm{M}^{-1}$ in nonpolar solvents to $\sim 15^{-1}$ in polar, hydrogen breaking solvents such as methanol. As demonstrated in Figure 6, the initially bound nanoparticles are removed from the surface after washing with methanol. Thus, reversibility of the film is retained, allowing the reversibly attach and remove the nanoparticles from the surface.

3.1.4. Nanorod Binding. Surface-modified nanorods were bound in a similar manner to the polymer films as the nanoparticles. Again, the binding of CdSe-nanorods with barbiturate-moieties (NR3) to those without specific interactions (TOPO-NR1) were compared on statistical polymers (polymer 3/s7, polymer $3 s / 8$ ) as well as block copolymers (polymer 3/b2 (10 mol\% cleft), polymer 3/b5 (1 mol\% cleft). As shown in Figure 7, the binding towards the statistically distributed receptors is relatively nonspecific, leading to only small differences in the binding.

Lower and higher amounts of receptors on the polymeric surface (see supplementary for detailed pictures) did not lead to different results. With block copolymers however (see Figure 8), the picture is different, as with $10 \mathrm{~mol} \%$ receptor (Figures $8(\mathrm{a}), 8(\mathrm{~b})$ ) the binding is highly specific with respect to NR3 ( specific interaction) and TOPONR1. At lower coverages of receptor (Figures 8(c), 8(d)) the 


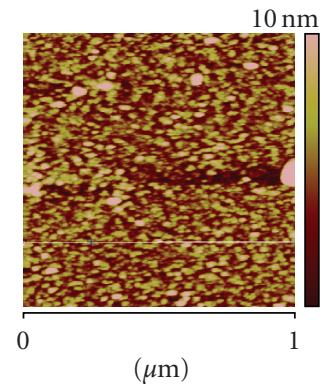

( $\mu \mathrm{m})$
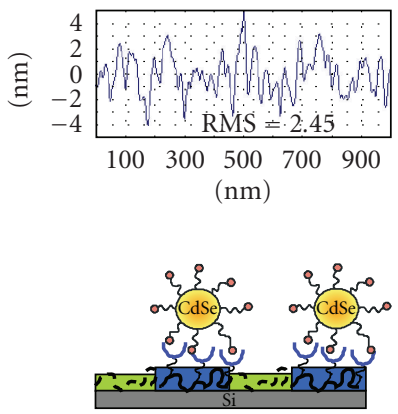

(a)

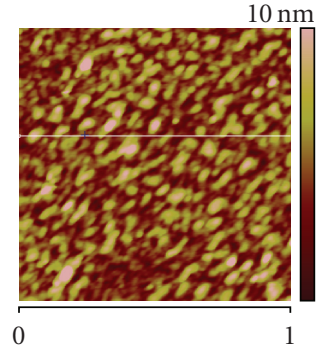

$(\mu \mathrm{m})$
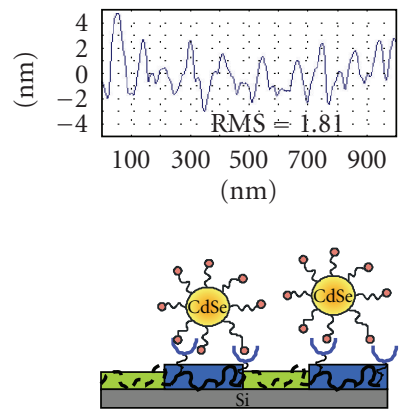

(b)

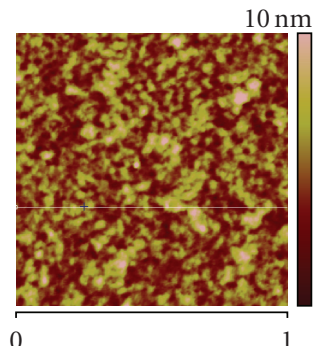

$(\mu \mathrm{m})$
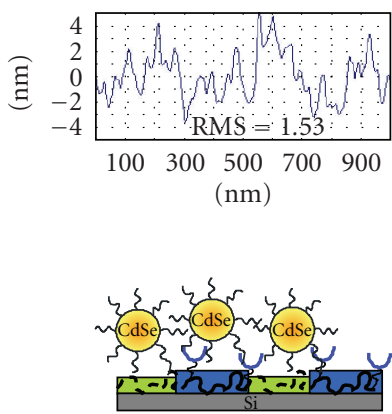

(c)
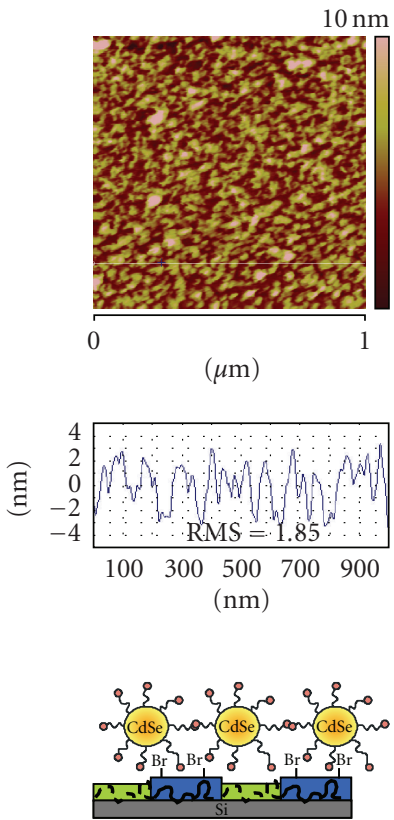

(d)

FIGURE 5: AFM-micrographs of attachment experiments of CdSe-nanoparticles to films made from block copolymers. (a) polymer 3/b2 ( $10 \mathrm{~mol} \%$ cleft) with NP4 (barbituric acid); (b) polymer 3/b5 (1 mol\% cleft) with NP4 (barbituric acid); (c) polymer 3/b5 (1 mol\% cleft) with NP2 (TOPO); (d) polymer 1/b1 (30 mol\% bromine) with NP2 (TOPO).

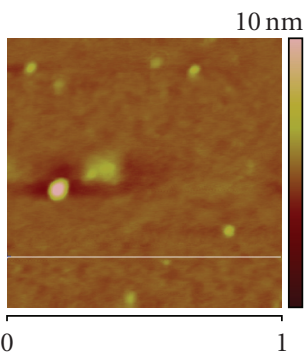

( $\mu \mathrm{m})$

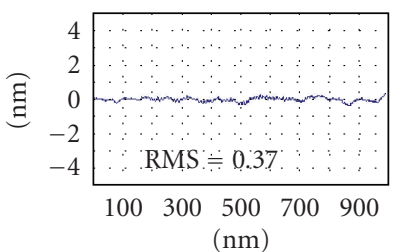

(nm)

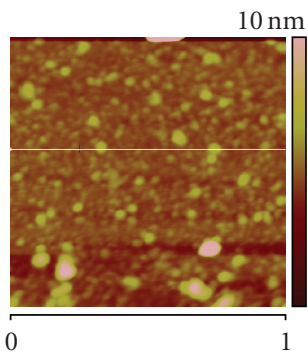

$(\mu \mathrm{m})$
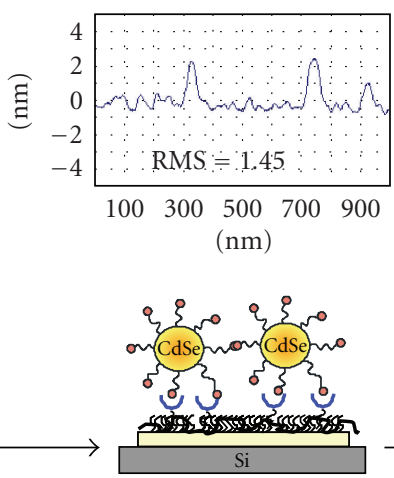

(b)

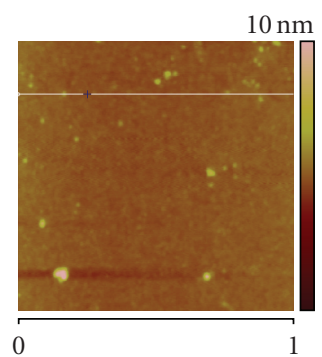

$(\mu \mathrm{m})$

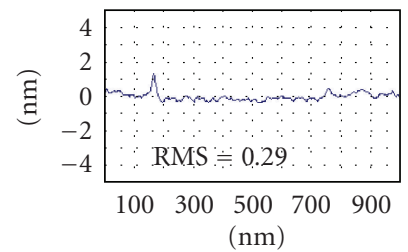

$\mathrm{CH}_{3} \mathrm{OH}$

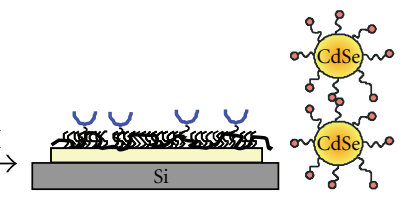

(c)

Figure 6: AFM-micrographs of removal-experiments of CdSe-nanoparticles from films made from statistical copolymer polymer 3/s6 ( $0.5 \mathrm{~mol} \%$ cleft) with NP4 (barbituric acid). (a) film made from polymer $3 / \mathrm{s} 6$ ( $0.5 \mathrm{~mol} \%$ cleft) (b) polymer $3 / \mathrm{s} 6$ ( $0.5 \mathrm{~mol} \% \mathrm{cleft})$ with NP4 (barbituric acid); (c) film after rinsing with methanol (24 hours), resulting in the removal of the nanoparticles. 


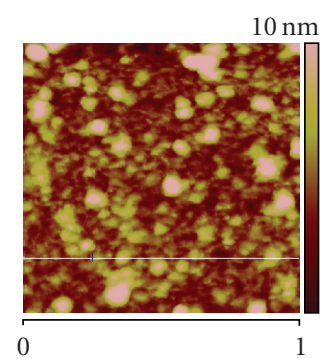

$(\mu \mathrm{m})$

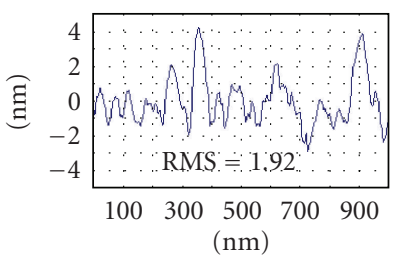

(a)

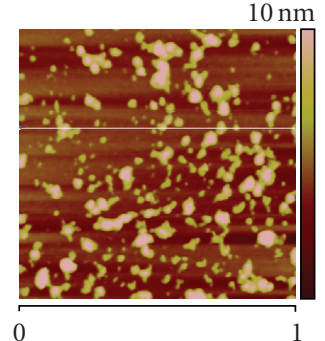

$(\mu \mathrm{m})$

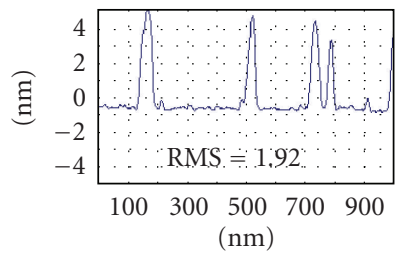

(b)

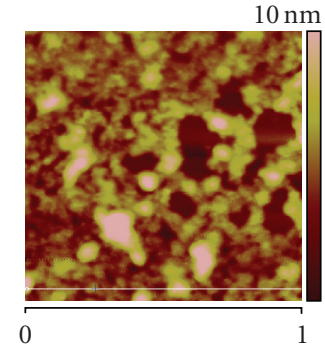

$(\mu \mathrm{m})$

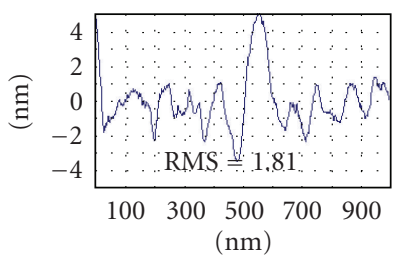

(c)

FIGURE 7: AFM-micrographs of attachment experiments of CdSe-nanorods to films made from statistical copolymers. (a) polymer 3/s7 ( $0.1 \mathrm{~mol} \%$ cleft) with NR3 (barbituric acid); (b) polymer $3 / \mathrm{s} 7$ (0.1 mol\% cleft) with NR1 (TOPO). (c) polymer $3 / \mathrm{s} 8(0.01 \mathrm{~mol} \%$ cleft) with NR3 (barbituric acid).

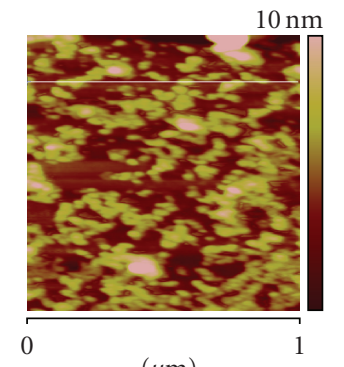

$(\mu \mathrm{m})$

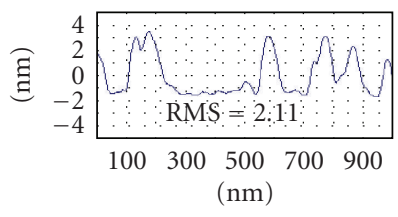

(a)

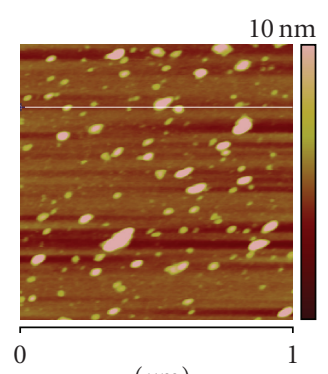

$(\mu \mathrm{m})$

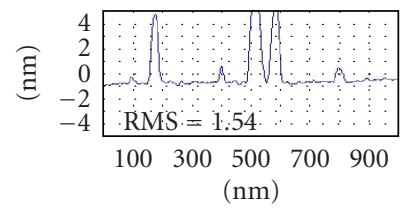

(b)

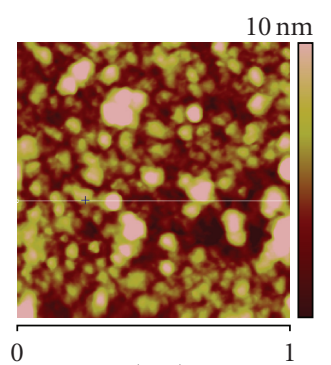

$(\mu \mathrm{m})$

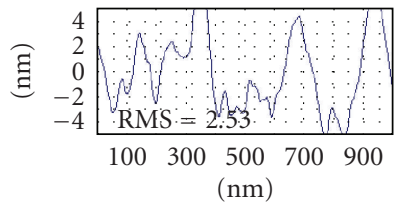

(c)

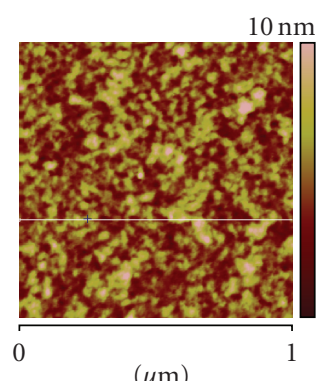

$(\mu \mathrm{m})$

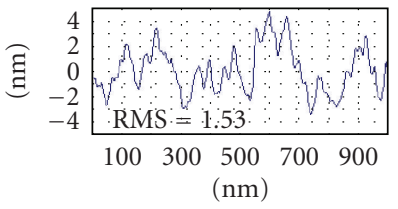

(d)

FIGURE 8: AFM-micrographs of attachment experiments of CdSe-nanorods to films made from block copolymers. (a) polymer 3/b2 (10 mol\% cleft) with NR3 (barbituric acid); (b) polymer 3/b2 (10 mol\% cleft) with NR1 (TOPO). (c) polymer 3/b5 (1 mol\% cleft) with NR3 (barbituric acid); (d) polymer 3/b5 (1 mol\% cleft) with NR1 (TOPO).

binding again is nonspecific, again revealing nonpolar effects between the NR-surface and the polymeric surface devoid of dense receptor layers. In both cases detachment of the nanorods can be achieved by addition of methanol (data not shown).

Significant, however, is the difference to the nanoparticle binding mentioned in the previous section: best and most selective nanorod binding (NR3) is achieved with the block copolymer polymer $3 / 62$ ( $10 \mathrm{~mol} \%$ cleft), whereas in the case of nanoparticles (NP4), the best and selective binding is achieved with the statistical copolymer polymer $3 / \mathrm{s} 5$ (1 mol\% cleft). This difference may be understood with respect to the number of interactions present on the respective nanosized object; assuming a surface area of the barbiturate of $\sim 7 \mathrm{~nm}^{2}$, about 44 units can be present on NR3, whereas only $\sim 11$ barbiturate-moieties can be present on a $\sim 5 \mathrm{~nm}$ sized CdSenanoparticle NP4. Due to geometrical reasoning, about in the case of NR3 $\sim 11$ barbiturates can interact with the surface, whereas in the case of NP4 3-4 can assume to be directed towards the polymer surface. In case of a $10 \mathrm{~mol} \%$ covered polymer film, about $1 / 5$ of the volume is covered with the Hamilton-receptor, whereas in a $1 \mathrm{~mol} \%$-covered film this amounts to $\sim 1 / 50$ (if all receptors would point upwards, and not to the silicon surface; $V_{\text {(monomer-unit) }} \sim$ $1 \mathrm{~nm}^{3} ; V_{\text {(Hamilton-receptor) }} \sim 25 \mathrm{~nm}^{3}$ ). We propose that the nanorods need a binding event over their whole surface (i.e., 


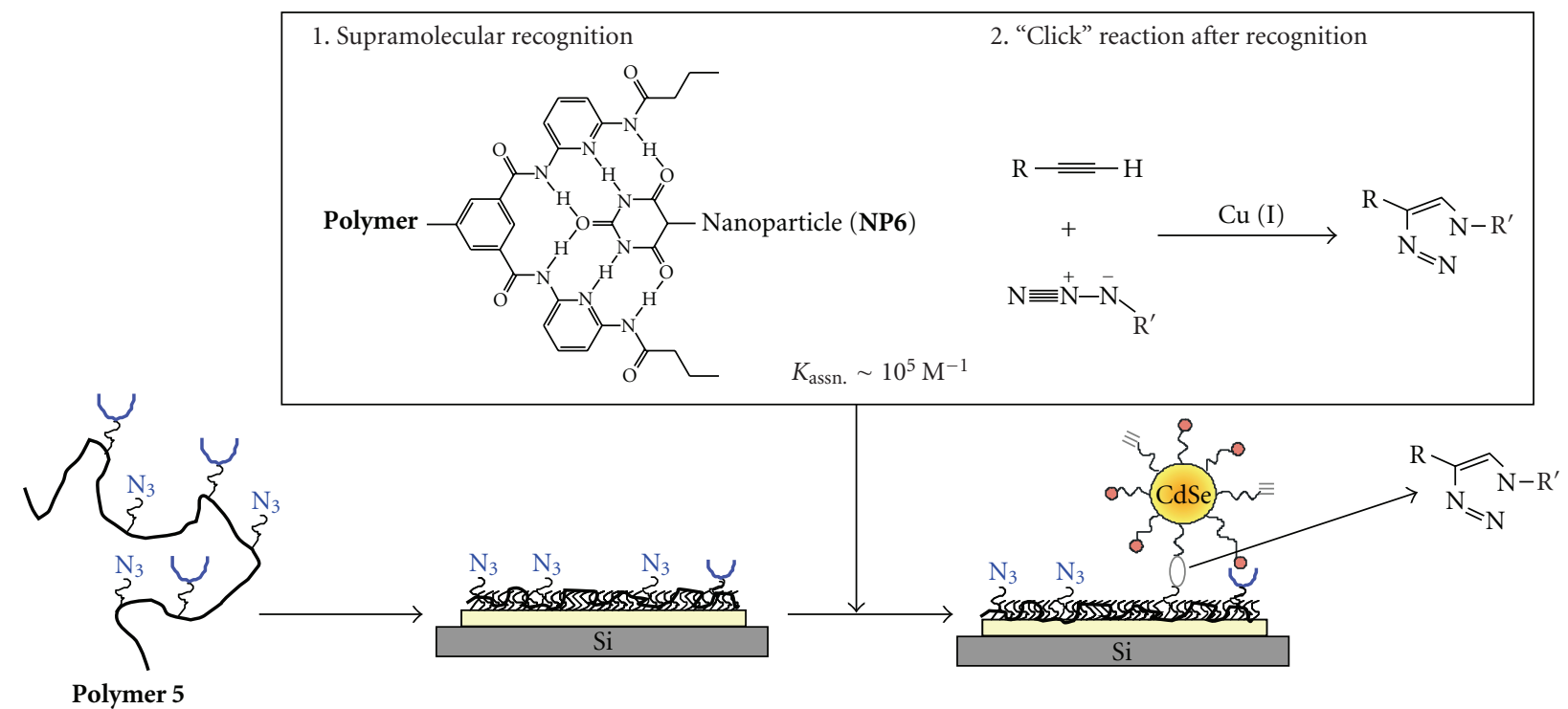

FIGURE 9: Schematic concept for the irreversible binding of nanoparticles to polymeric surfaces 1st: film-formation from polymer 5; 2nd: supramolecular recognition and 3rd: azide/alkine-"click"-reaction.
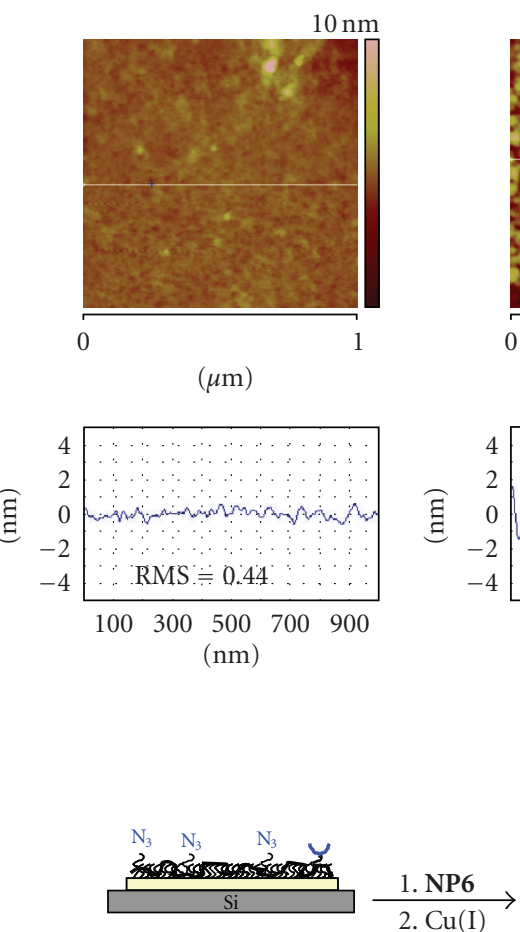

(a)

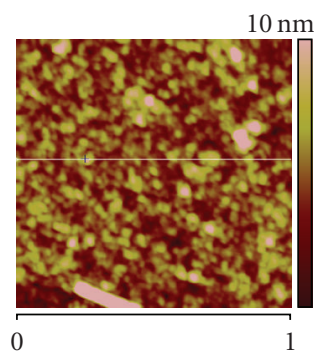

$(\mu \mathrm{m})$
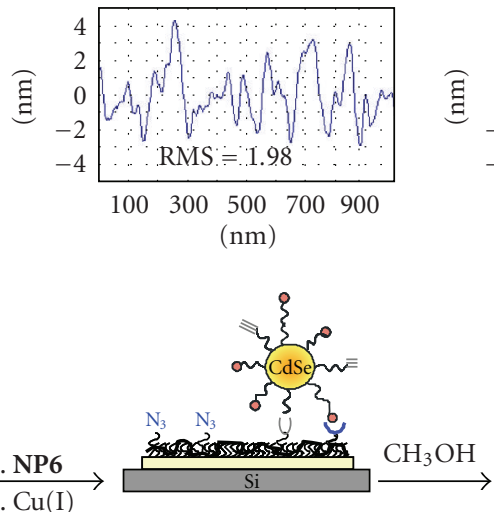

(b)

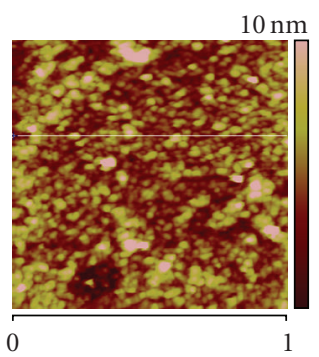

$(\mu \mathrm{m})$
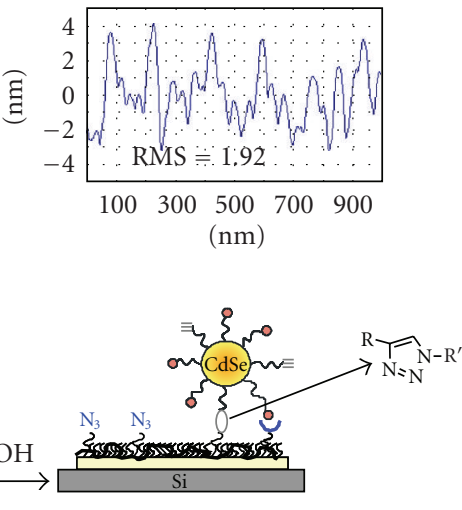

(c)

FIGURE 10: AFM-micrographs of irreversible binding experiments of CdSe-nanoparticles from films made from statistical copolymer polymer 5 (10 mol\% cleft, $40 \mathrm{~mol} \%$ azide-moieties) with NP6 (barbituric acid). (a) film made from polymer 5 ( $10 \mathrm{~mol} \%$ cleft, $40 \mathrm{~mol} \%$ azidemoieties) (b) polymer 5 (10 mol\% cleft, 40 mol\% azide-moieties) with NP6 (barbituric acid) after incubation with Cu(I)Br (c) film after rinsing with methanol (24 hours), resulting still in the stable attachment of the nanoparticles.

at the "tail" as well as via the "head," therefore a denser layer of Hamilton-receptors is needed for a stable binding. In the case of the nanoparticle, geometry allows for a better binding and usage of the presented Hamilton-receptors - therefore a lower amount of themis needed to effect vbinding onto the surface.
3.1.5. Irreversible Nanoparticle Binding. As we have effected reversible binding, irreversible binding is projected by the following experiments (see Figure 9): a statistical polymer (polymer 5) bearing both, Hamilton-receptor moieties (cleft) and pendant azide-moieties as prepared into a film. Nanoparticles (NP6), bearing the barbiturate-recognition 
moiety and residual acetylenic moieties are bound to the surface. After binding, $\mathrm{Cu}(\mathrm{I})$-salts are added to the solution in order to induce the azide/alkine-"click"-reaction between the azide-moieties on the polymer with the alkinemoieties on NP6, thus fixing the nanoparticle to the surface after recognition. The underlying experiment is shown in Figure 10.

The initial smooth polymer film of polymer 5 (Figure 10(a)) is incubated with a solution of NP6, whereupon a dense layer of NP is observed (Figure 10(b)). The concentration of the Hamilton-receptor in polymer 5 is about $1 \mathrm{~mol} \%$, consistent with the optimal, most selective, and specific results obtained by the CdSe-NP-binding reported in the previous chapter. After addition of $\mathrm{Cu}(\mathrm{I})$ ions to the solution, the nanoparticles cannot be detached by incubation with methanol ( 24 hours) from the polymer film as seen in Figure 10(c). Thus a stable addition of the NPs due to the "click"-reaction via the triazole-bond can be assumed.

\section{Conclusions}

In summary we have reported the reversible and irreversible addition of CdSe-nanoparticles and CdSe-nanorods to polymer films via supramolecular interactions. CdSenanoparticles and the respective nanorods $(20 \mathrm{~nm} ; 7 \mathrm{~nm})$ behave differently with respect to the needed density of matching supramolecular interactions on the polymer surface : whereas CdSe-NP's ( $5 \mathrm{~nm}$ ) show optimal and specific attachment to films derived from a statistical copolymer with about $1 \mathrm{~mol} \%$ Hamilton-receptor, in the case of nanorods a block copolymer with about $10 \mathrm{~mol} \%$ Hamilton-receptor shows optimal results. In both cases, a reversible detachment is possible by use of methanol. Irreversible binding can be achieved by using polymers and nanoparticles with residual azide/alkine-groups on their surface, thus allowing a covalent fixation after the recognition-event by the hydrogen bonding system. The present method is highly versatile, as both-the polymer and the nanoparticle/nanorod-surfaces can be engineered nearly indefinitely. Moreover, in light of the growing interest for CdSe-nanorods for solar cell applications, this method allows to direct binding of highly luminescent $\mathrm{CdSe}$-nanorods to specific locations of polymers and polymeric surfaces.

\section{Acknowledgment}

The authors would thank the FWF, Project 18740B03 for financial support.

\section{References}

[1] A. Burns, H. Ow, and U. Wiesner, "Fluorescent core-shell silica nanoparticles: towards "Lab on a Particle" architectures for nanobiotechnology," Chemical Society Reviews, vol. 35, no. 11, pp. 1028-1042, 2006.

[2] D. J. Milliron, I. Gur, and A. P. Alivisatos, "Hybrid organicnanocrystal solar cells," MRS Bulletin, vol. 30, no. 1, pp. 41-44, 2005.
[3] P. Ghosh, G. Han, M. De, C. K. Kim, and V. M. Rotello, "Gold nanoparticles in delivery applications," Advanced Drug Delivery Reviews, vol. 60, no. 11, pp. 1307-1315, 2008.

[4] M.-C. Daniel and D. Astruc, "Gold nanoparticles: assembly, supramolecular chemistry, quantum-size-related properties, and applications toward biology, catalysis, and nanotechnology," Chemical Reviews, vol. 104, no. 1, pp. 293-346, 2004.

[5] S. Kinge, M. Crego-Calama, and D. N. Reinhoudt, "Selfassembling nanoparticles at surfaces and interfaces," ChemPhysChem, vol. 9, no. 1, pp. 20-42, 2008.

[6] Y. Min, M. Akbulut, K. Kristiansen, Y. Golan, and J. Israelachvili, "The role of interparticle and external forces in nanoparticle assembly," Nature Materials, vol. 7, no. 7, pp. 527-538, 2008.

[7] W. H. Binder, "Supramolecular assembly of nanoparticles at liquid-liquid interfaces," Angewandte Chemie International Edition, vol. 44, no. 33, pp. 5172-5175, 2005.

[8] L. M. Demers, D. S. Ginger, S.-J. Park, Z. Li, S.-W. Chung, and C. A. Mirkin, "Direct patterning of modified oligonucleotides on metals and insulators by dip-pen nanolithography," Science, vol. 296, no. 5574, pp. 1836-1838, 2002.

[9] H. Duan, D. Wang, D. G. Kurth, and H. Möhwald, "Directing self-assembly of nanoparticles at water/oil interfaces," Angewandte Chemie, vol. 116, no. 42, pp. 5757-5760, 2004.

[10] A. Böker, Y. Lin, K. Chiapperini, et al., "Hierarchical nanoparticle assemblies formed by decorating breath figures," Nature Materials, vol. 3, no. 5, pp. 302-306, 2004.

[11] R. B. Thompson, V. V. Ginzburg, M. W. Matsen, and A. C. Balazs, "Predicting the mesophases of copolymer-nanoparticle composites," Science, vol. 292, no. 5526, pp. 2469-2472, 2001.

[12] M. R. Bockstaller, R. A. Mickiewicz, and E. L. Thomas, "Block copolymer nanocomposites: perspectives for tailored functional materials," Advanced Materials, vol. 17, no. 11, pp. 1331-1349, 2005.

[13] A. C. Balazs, T. Emrick, and T. P. Russell, "Nanoparticle polymer composites: where two small worlds meet," Science, vol. 314, no. 5802, pp. 1107-1110, 2006.

[14] A. Haryono and W. H. Binder, "Controlled arrangement of nanoparticle arrays in block-copolymer domains," Small, vol. 2, no. 5, pp. 600-611, 2006.

[15] W. H. Binder and R. Zirbs, "Supramolecular polymers and networks with hydrogen bonds in the main- and side-chain," in Hydrogen Bonded Polymers, vol. 207 of Advances in Polymer Science, pp. 1-78, Springer, Berlin, Germany, 2007.

[16] H. Xu, R. Hong, T. Lu, O. Uzun, and V. M. Rotello, "Recognition-directed orthogonal self-assembly of polymers and nanoparticles on patterned surfaces," Journal of the American Chemical Society, vol. 128, no. 10, pp. 3162-3163, 2006.

[17] H. Xu, S. Srivastava, and V. M. Rotello, "Nanocomposites based on hydrogen bonds," in Hydrogen Bonded Polymers, vol. 207 of Advances in Polymer Science, pp. 179-198, Springer, Berlin, Germany, 2007.

[18] W. H. Binder, C. Kluger, C. J. Straif, and G. Friedbacher, "Directed nanoparticle binding onto microphase-separated block copolymer thin films," Macromolecules, vol. 38, no. 23, pp. 9405-9410, 2005.

[19] R. Zirbs, F. Kienberger, P. Hinterdorfer, and W. H. Binder, "Directed assembly of Au nanoparticles onto planar surfaces via multiple hydrogen bonds," Langmuir, vol. 21, no. 18, pp. 8414-8421, 2005. 
[20] W. H. Binder, S. Bernstorff, C. Kluger, L. Petraru, and M. J. Kunz, "Tunable materials from hydrogen-bonded pseudo block copolymers," Advanced Materials, vol. 17, no. 23, pp. 2824-2828, 2005.

[21] S. S. Kinge, M. Crego-Calama, and D. N. Reinhoudt, "Gold nanoparticle assemblies through hydrogen-bonded supramolecular mediators," Langmuir, vol. 23, no. 17, pp. 8772-8777, 2007.

[22] M. J. W. Ludden, A. Mulder, R. Tampé, D. N. Reinhoudt, and J. Huskens, "Molecular printboards as a general platform for protein immobilization: a supramolecular solution to nonspecific adsorption," Angewandte Chemie International Edition, vol. 46, no. 22, pp. 4104-4107, 2007.

[23] V. V. Rostovtsev, L. G. Green, V. V. Fokin, and K. B. Sharpless, "A stepwise huisgen cycloaddition process: copper(I)catalyzed regioselective "ligation" of azides and terminal alkynes," Angewandte Chemie International Edition, vol. 41, no. 14, pp. 2596-2599, 2002.

[24] C. W. Tornøe, C. Christensen, and M. Meldal, "Peptidotriazoles on solid phase: [1,2,3]-triazoles by regiospecific copper(I)-catalyzed 1,3-dipolar cycloadditions of terminal alkynes to azides," Journal of Organic Chemistry, vol. 67, no. 9, pp. 3057-3064, 2002.

[25] W. H. Binder and C. Kluger, "Azide/alkyne-"click" reactions: applications in materials science and organic synthesis," Current Organic Chemistry, vol. 10, no. 14, pp. 1791-1815, 2006.

[26] W. H. Binder and R. Sachsenhofer, "“click” chemistry in polymer and materials science," Macromolecular Rapid Communications, vol. 28, no. 1, pp. 15-54, 2007.

[27] W. H. Binder and R. Sachsenhofer, "“click" chemistry in polymer and material science: an update," Macromolecular Rapid Communications, vol. 29, no. 12-13, pp. 952-981, 2008.

[28] W. H. Binder and C. Kluger, "Combining ring-opening metathesis polymerization (ROMP) with sharpless-type "click" reactions: an easy method for the preparation of side chain functionalized poly(oxynorbornenes)," Macromolecules, vol. 37, no. 25, pp. 9321-9330, 2004.

[29] W. H. Binder, C. Kluger, M. Josipovic, C. J. Straif, and G. Friedbacher, "Directing supramolecular nanoparticle binding onto polymer films: film formation and influence of receptor density on binding densities," Macromolecules, vol. 39, no. 23, pp. 8092-8101, 2006.

[30] C. Kluger and W. H. Binder, "Functionalized poly(oxanorbornene)-block-copolymers: preparation via romp/ $\backslash$ linebreak click-methodology," Journal of Polymer Science A, vol. 45, no. 3, pp. 485-499, 2007.

[31] W. H. Binder, R. Sachsenhofer, C. J. Straif, and R. Zirbs, "Surface-modified nanoparticles via thermal and $\mathrm{Cu}(\mathrm{i})$ mediated "click" chemistry: generation of luminescent CdSe nanoparticles with polar ligands guiding supramolecular recognition," Journal of Materials Chemistry, vol. 17, no. 20, pp. 2125-2132, 2007.

[32] Z. A. Peng and X. Peng, "Nearly monodisperse and shapecontrolled CdSe nanocrystals via alternative routes: nucleation and growth," Journal of the American Chemical Society, vol. 124, no. 13, pp. 3343-3353, 2002. 

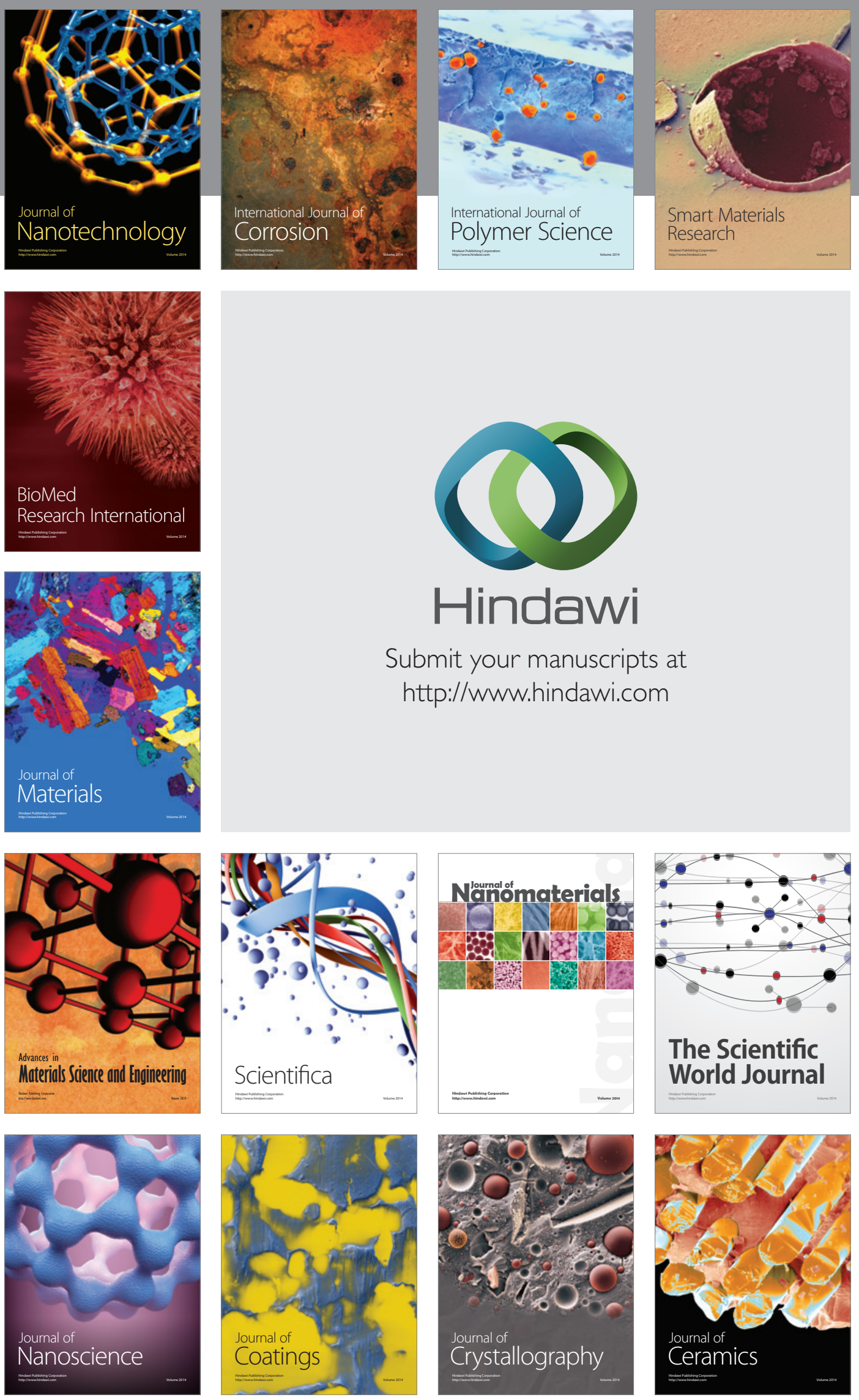

The Scientific World Journal

Submit your manuscripts at

http://www.hindawi.com

\section{World Journal}

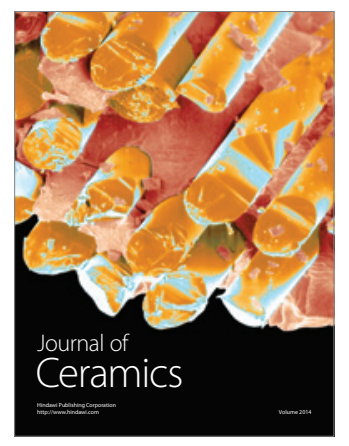

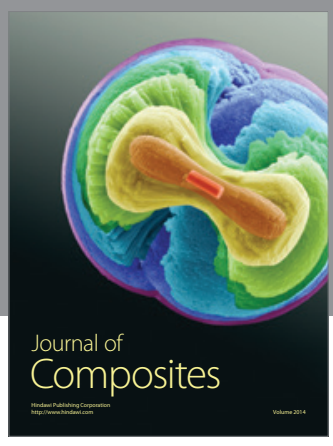
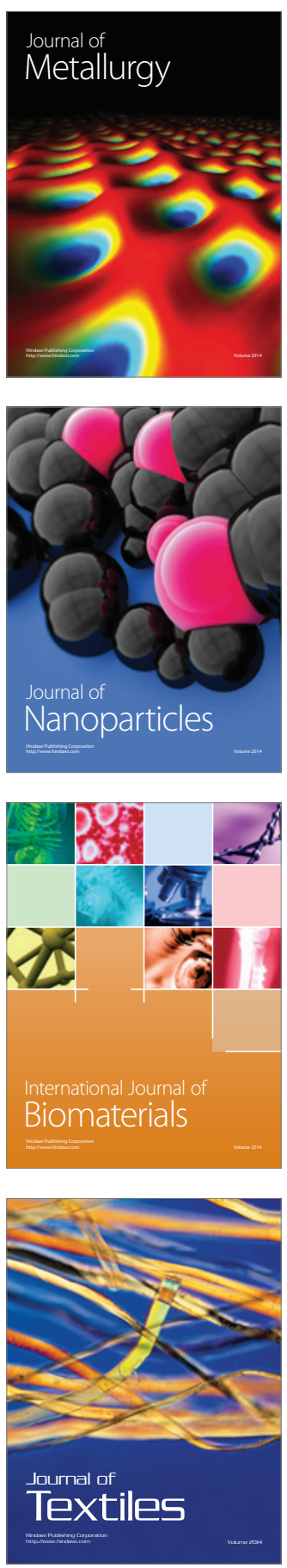